\title{
The effects of parental leave extension on training for young women
}

\author{
Patrick A. Puhani · Katja Sonderhof
}

Received: 15 October 2008 / Accepted: 22 October 2009 /

Published online: 26 November 2009

(C) Springer-Verlag 2009

\begin{abstract}
Using three datasets for West Germany, we estimate the effect of the extension of parental leave from between 10 and 18 to 36 months on young women's participation in job-related training. Specifically, we employ difference-in-differences identification strategies using control groups of older women and young and older men. We find that parental leave extension negatively affects job-related training for young women, even if they do not have children, especially when the focus is on employer-arranged training. There is tentative evidence that young women partly compensated for this reduction in employer-arranged training by increasing training on their own initiative.
\end{abstract}

Keywords Policy • Evaluation • Education

JEL Classification $\mathrm{J} 16 \cdot \mathrm{J} 24 \cdot \mathrm{J} 83$

Responsible editor: Deborah Cobb-Clark

P. A. Puhani $(\bowtie) \cdot$ K. Sonderhof

Institut für Arbeitsökonomik, Leibniz Universität Hannover,

Königsworther Platz 1, 30167 Hannover, Germany

e-mail: puhani@aoek.uni-hannover.de

P. A. Puhani

SEW, University of St. Gallen, St. Gallen, Switzerland

P. A. Puhani

ERMES, Université Paris II, Paris, France

P. A. Puhani

IZA, Bonn, Germany 


\section{Introduction}

Most industrialized countries have some form of maternity or parental leave policy that effectively grants employment protection to women around childbirth and in some cases to either parent for an even longer period after childbirth. Arguments in favor of this employment protection refer to the wellbeing of both young children and their mothers. From a labor perspective, employment protection through maternity leave might increase the attachment of mothers to their employer or the labor force in general. However, it may also have the opposite effect in that maternity leave combined with maternity benefits can be seen as a subsidy to leave the labor market temporarily with potential long-term consequences.

Whereas previous studies on maternity leave with employment and wages as outcome variables have frequently discussed the role of human capital accumulation and depreciation, we know of no study relating human capital investments such as training directly to maternity or parental leave (which is mostly taken by mothers). ${ }^{1}$ Therefore, in this paper, we estimate the effect of prolonged parental leave on the human capital investments of women of working and childbearing age. ${ }^{2}$ To this end, we exploit the natural experiment of an extension in the employment protection (parental leave) period in Germany from between 10 and 18 to 36 months, which propelled Germany to the top position in the ranking of legislatively mandated maternity/parental leave durations among industrialized countries. ${ }^{3}$ To assess the effect of this reform on human capital investments of young female workers, we draw on

\footnotetext{
${ }^{1}$ Since 1986, maternity leave in Germany can be taken by either the mother or the father and is, therefore, called parental leave. But according to the German Federal Ministry of Families, Seniors, Women, and Youth, only $1.5 \%$ of fathers made use of this opportunity up to 2001, a share that has risen to about $5 \%$ by 2004 (see the Ministry's website http://www. bmfsfj.de/bmfsfj/generator/BMFSFJ/familie,did=20212.html, in German). If men were seen by employers as treated by the reforms that we subsequently analyze, the effects we estimate in the following would be lower bounds for the reform effects. However, given the small share of men taking leave during our observation period and anecdotal evidence that men usually took very short leaves, we do not believe that employers perceived men as being par of the treatment group of the parental leave extension reforms.

${ }^{2}$ Present discounted value of earnings, of which wage profiles and employment histories are major ingredients, might be the most appropriate outcome variable for the financial impact of parental/maternity leave. However, measurement of the impacts on overall lifecycle wage and employment profiles is complicated by the frequent lack of long panel data. Conversely, impacts on wages at a certain point in the lifecycle may fail to take account of effects like steepened wage profiles. For example, when women have to bear a higher share of the costs of firm-specific training because of extended parental/maternity leave, their early-career wages may fall, although Hashimoto's (1981) model would predict that they will also reap a higher share of the returns later in their careers. Thus, without data on lifecycle wage profiles, estimates with wages as the outcome might be difficult to interpret.

${ }^{3}$ See http://www.childpolicyintl.org/issuebrief/issuebrief5table1.pdf.
} 
three individual-level datasets, all of which ask information on job-related training for women and men of different age groups.

It is well-established empirically that women are generally less attached to the labor force than men and that they receive less job-related training. For example, Barron et al. (1993) show that US workers with weaker attachment to the labor market are allocated to jobs offering less training, while women are employed in positions associated with shorter durations of job-related training. Similarly, Royalty (1996) finds a significant relationship in the US between the predicted probability of job turnover and the probability of receiving training. Thus, the fact that women change their job positions more frequently accounts for about one fourth of the gender gap in training. For Britain, Green (1991) analyzes the differences in job-related training between young women and men and between older women and men. In comparison to young men, young women have less than half the chances of receiving training, although no differences are found between older women and men.

Although these studies do not explicitly relate maternity leave to the incidence of training for women, they implicitly raise the question of whether prolonged maternity leave might affect job-related training for young women. The effect on training might be negative because a very long maternity leave reduces a young woman's labor market attachment, at least for the duration of the leave. ${ }^{4}$ As a consequence, employers should be less likely to invest in young women's human capital and place them in career paths with less training. Theoretically, the opposite effect might also prevail: if employers are forced to reemploy a woman even after a long leave, they might make the best of the situation and make up for lost human capital through intensified training (if the return to that investment is positive and higher than the return to alternative strategies such as finding ways to still fire the worker, for example through generous severance payments or other means). In the end, it is an empirical question which effect predominates.

Previous research has analyzed the relationships between both maternity leave and labor force participation and maternity leave and wages. For instance, Waldfogel (1999) finds no negative effects for the Family and Medical Leave Act's introduction of a 12-week maternity leave on the wages or employment of young women. Baum (2003) and Hashimoto et al. (2004) also find the effects to be negligible. Indeed, Waldfogel (1998) suggests that maternity leave may even increase young women's employment and wages, a finding corroborated by Zveglich and van der Meulen Rodgers's (2003) investigation of a similar reform in Taiwan that introduced an 8-week maternity leave. Nevertheless, these findings contrast with those of Lai and Masters (2005)

\footnotetext{
${ }^{4}$ Job stability and thus the opportunity for investment in firm-specific human capital is much higher in Germany than it is in the USA. For example, Auer and Cazes (2000) report that, in 1990, the annual job failure rate of jobs with up to 1 year of tenure was $63.4 \%$ and $24 \%$ in the USA and Germany, respectively.
} 
for Taiwan, as well as with Gruber's (1994) finding of a negative effect on wages of variations in maternity benefits across the US. They also contrast with the results of European studies that use reforms or other control group designs with longer parental/maternity leave periods (up to 3 years). Among these, Ondrich et al. (1996, 1999, 2003) and Lalive and Zweimüller (2005), based on data from Germany and Austria, respectively, find that extended parental/maternity leave results in short-run reductions in labor supply, while Schönberg and Ludsteck (2007) estimate negative long-run effects on wages in Germany. Likewise, in an analysis of policy variation in a panel of European countries, Ruhm (1998) reports increased employment due to parental leave (de facto maternity leave) but lower wages.

The remainder of this paper is organized as follows: Section 2 provides an overview of parental leave regulations in Germany, especially with respect to the 1992 reform investigated here. Section 3 describes the datasets and the research design, after which Section 4 presents the difference-in-differences and difference-in-trend-shifts estimates of the effects of parental leave extension on job-related training for women of childbearing age. Overall, these estimates show that the extension reduced training for young women, even for those who do not have children. A separate look at different types of training shows that it is particularly employer-arranged training that has been reduced by the extension of parental leave. Point estimates suggest that young women are in return trying to compensate the reduction in employer-arranged training by increasing training on their own initiative. Section 5 concludes the paper.

\section{Parental leave in Germany}

The duration of parental leave as guaranteed by law in Germany exceeds that of other industrialized countries. For example, only since 1993 have US federal regulations given women the right to take a 12-week maternity leave from work, even though many firms previously had their own maternity leave schemes. In contrast, as early as 1952, Germany enacted a law "protecting mothers" (Mutterschutzgesetz) with a mandated 12-week maternity leave, called "mother protection period," which was extended in 1965 to 14 weeks (i.e., 6 weeks before and 8 weeks after the predicted birth date). In 1979, besides the 14 weeks of mother protection period, mothers could also take an additional 4-month maternity leave. Since 1986, this maternity leave has been replaced by parental leave and can be taken either by the mother or the father (Bundeserziehungsgeldgesetz). Parental leave was lengthened to 10 months after birth (thus, including the 8 weeks of the mother protection period after childbirth) in 1986 and repeatedly increased to 36 months until 1992 (see Table 1 and the more detailed descriptions in Ondrich et al. 1996, 1999). The largest increase was the 1992 extension of the maximum duration from 18 to 36 months. All expansions of parental leave apply to mothers of 
Table 1 Increase of maximum maternity/parental leave duration

\begin{tabular}{|c|c|c|}
\hline Year & Duration & Explanation \\
\hline 1952 & 12 weeks & $\begin{array}{l}\text { Introduction of a 12-week mother protection period (Mutterschutz), } \\
6 \text { weeks before and } 6 \text { weeks after birth of the child. Women are } \\
\text { not allowed to work during this period. The average wage of the } \\
\text { last } 3 \text { months before pregnancy is paid partly by the employer and } \\
\text { partly by the health insurance. }\end{array}$ \\
\hline 1965 & 14 weeks & $\begin{array}{l}\text { Duration of mother protection period extended to } 14 \text { weeks }-6 \text { weeks } \\
\text { before and } 8 \text { weeks after childbirth. }\end{array}$ \\
\hline 1979 & 4 months & $\begin{array}{l}\text { Introduction of a 4-months maternity leave (Mutterschaftsurlaub), which } \\
\text { can be taken subsequent to the } 14 \text { weeks' mother protection period. }\end{array}$ \\
\hline 1986 & 10 months & $\begin{array}{l}\text { Parental leave of } 10 \text { months following childbirth can be taken by either } \\
\text { the mother or the father and is therefore called parental leave. The } \\
\text { person on parental leave is allowed to work for up to } 19 \text { hours per } \\
\text { week. Parental leave can be exchanged once between mother and } \\
\text { father. Parental benefits (Erziehungsgeld) of up to } 600 \text { deutschmarks } \\
\text { (about } 300 \text { euros) per month are paid by the Government for } 10 \text { months, } \\
\text { depending on the income of the family. }\end{array}$ \\
\hline 1988 & 12 months & $\begin{array}{l}\text { Duration of parental leave extended to } 12 \text { months for parents of } \\
\text { children born later than June } 30 \text { th } 1988 \text {. Monthly parental benefits of } \\
\text { up to } 600 \text { deutschmarks (about } 300 \text { euros) are paid for } 12 \text { months, } \\
\text { depending on the income of the family. }\end{array}$ \\
\hline 1989 & 15 months & $\begin{array}{l}\text { Duration of parental leave extended to } 15 \text { months for parents of } \\
\text { children born later than June } 30 \text { th } 1989 \text {. Monthly parental benefits of } \\
\text { up to } 600 \text { deutschmarks (about } 300 \text { euros) are paid for } 15 \text { months, } \\
\text { depending on the income of the family. }\end{array}$ \\
\hline 1990 & 18 months & $\begin{array}{l}\text { Duration of parental leave extended to } 18 \text { months for parents of } \\
\text { children born later than June } 30 \text { th } 1990 \text {. Monthly parental benefits of } \\
\text { up to } 600 \text { deutschmarks (about } 300 \text { euros) are paid for } 18 \text { months, } \\
\text { depending on the income of the family. }\end{array}$ \\
\hline 1992 & 36 months & $\begin{array}{l}\text { Duration of parental leave extended to } 36 \text { months for parents of } \\
\text { children born later than January 1st } 1992 \text {. Parental leave can be } \\
\text { exchanged three times between mother and father. }\end{array}$ \\
\hline 1993 & 36 months & $\begin{array}{l}\text { Monthly parental benefits of up to } 600 \text { deutschmarks (about } 300 \text { euros) } \\
\text { are paid for } 24 \text { months, depending on the income of the family. }\end{array}$ \\
\hline 2001 & 36 months & $\begin{array}{l}\text { Both parents can go on parental leave at the same time. Both are } \\
\text { allowed to work for up to } 30 \text { hours per week. If parental leave is } \\
\text { taken only for } 12 \text { months or less, parental benefits increase to up to } \\
900 \text { deutschmarks ( } 460 \text { euros), depending on the income of the family. }\end{array}$ \\
\hline
\end{tabular}

All employed mothers or fathers can go on parental leave and return to their previous employer afterwards (however, temporary contracts do not have to be renewed during parental leave). All women who are employed are eligible for maternity allowance (Mutterschaftsgeld) during the 14 weeks of the mother protection period. It is paid partly by the employer and partly by the statutory health insurance or the government, depending on the mother's heath insurance. Child-raising benefits (Erziehungsgeld) are paid to all parents as long as one parent is not working more than $19 \mathrm{~h}$ (since 2001: $30 \mathrm{~h}$ ) per week and as long as family income is not too high. For exact information on income limits, see Ondrich et al. (1996) p. 250251. This system underwent major changes in 2007, since when benefits depend positively on income and parental leave of fathers is subsidized by paying parental allowance longer if fathers go on parental leave for at least 2 months. Sources: Kreyenfeld (2001), Dienel (2002), Ondrich et al. (1996), Federal Ministry of Families, Seniors, Women, and Youth (BMFSFJ): http://www.bmfsfj.de/bmfsfj/static/broschueren/erziehungsgeld/elternzeit.htm 
children born after the introduction of the reform only. ${ }^{5}$ As Table 1 shows, most of the expansions in parental leave also involved an increase in the duration of parental benefit payments, which might have contributed to the incentive to take a longer leave, although Ondrich et al. (1996) do not find significant effects of parental benefits on the return-to-work probability.

One intention of policy makers when increasing the maximum parental leave duration was to facilitate extended childcare by the parents without them risking to lose their jobs in the process. Another was to improve the welfare of children (Dienel 2002, p.108). Since public-funded childcare facilities for children younger than 3 years of age are not generally available in West Germany (having only recently gained broader political support in the western part of the country), all parents are supposed to be given the opportunity to care for their children for up to 3 years.

By law, parents have the right to return to a job with their previous employer following parental leave, not necessarily the same job but one comparable to that held before the leave. Nevertheless, the short-term effect of extended parental leave on labor force participation is likely to be negative simply through the incentive given by parental leave to leave the labor market temporarily. For example, Ondrich et al. (1996, 1999, 2003) and Weber (2004) find that a longer duration of parental leave has a negative impact on the probability of women returning to the labor market, a finding also reported by Lalive and Zweimüller (2005) for Austria. For the USA, Klerman and Leibowitz (1990) show that because of better childcare facilities and less maternity leave protection, mothers return to the labor market sooner than in the past. On the other hand, Waldfogel et al. (1999) show that maternity leave coverage increases the likelihood that a mother returns to her previous employer in the USA, Britain, and Japan, which is consistent with the design of maternity leave regulations. Waldfogel and Berger (2004) report that more than $80 \%$ of US women working before childbirth return to work within 12 months after childbirth, while $55 \%$ return within 12 weeks after childbirth. In Germany, however, around 55\% of all women working before a first birth return to the labor market within only a much longer time period, i.e., 24 months (Gustafsson et al. 1996), and Germany has one of the lowest employment rates of mothers even 8 years after birth, that is 5 years after the maximum parental leave period has ended (Gutiérrez-Domènech 2005).

Figure 1 shows calculations of the average maternity/parental leave durations for women working before childbirth based on biographical information from the German Socioeconomic Panel (GSOEP). In the upper graph, we calculate the average period out of the labor force due to childbirth by adding the duration of formal parental leave to the number of months after the

\footnotetext{
${ }^{5}$ During parental leave, child-raising benefits were paid during our observation period, as described in Table 1 (about 300 euros per month). These benefits partly depended on the income of the parents and there were some smaller changes concerning the income thresholds. For more details, see Ondrich et al. (1996). Eligible for parental leave are all parents who work as employees. However, temporary contracts do not have to be renewed during the leave period.
} 


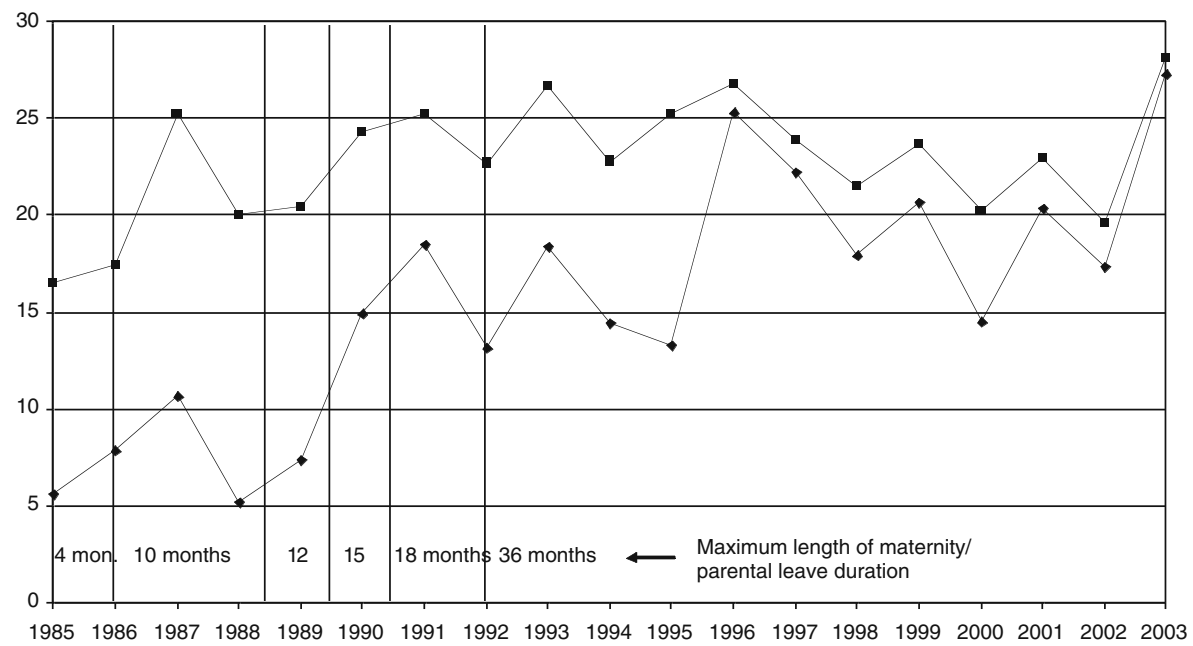

$\multimap-$ Mother worked before and directly after maternity/parental leave (max=36 months break)

- Mother worked before but not directly after maternity/parental leave (max=36 months break)

Fig. 1 Average length of parental leave taken by mothers (in months). All durations longer than 36 months were censored to 36 months in order to show how the extension of parental leave to 36 months changed leave taken up to that limit. Vertical lines show the timing of the reforms to increase parental leave duration. The length of parental leave is measured in months. We only consider women between 20 and 35 years of age. The years in the graph refer to the year in which parental leave started. In the top line, we add the durations of official maternity/parental leave and post maternity leave career breaks, which are common in Germany. The lower line only considers official maternity/parental leave for mothers who return to the labor market directly after their official maternity/parental leave. The jump between 2002 and 2003 is probably explained by sample attrition that is not sufficiently accounted for by the sampling weights provided by the GSOEP. Source: German Socio-Economic Panel (GSOEP); own calculations

leave until a mother was reemployed. In the lower graph, we plot the average duration of parental leave taken by mothers who return to work directly when maternity/parental leave ends. The difference between the two lines is driven by the fact that in Germany, many mothers stay at home with their children for many years, even after their parental leave entitlement has run out. It should be noted that we have very few observations (between 10 and 75 per year), so the numbers shown here have high sampling variance. All results are weighted using sampling weights.

For both graphs, we have censored all durations at 36 months (the maximum parental leave duration in Germany since 1992) because we are only interested in how far parental leave extension drives career breaks up to that limit. As it turns out, parental leave extension is associated with an increase in average career break durations due to childbirth. Keeping in mind the sampling variance, career break durations increased from around 20 months in the late 1980 s to around 25 months in the early 1990s. If we only consider mothers who return to work directly following parental leave (which may be for shorter periods than the legal limit), we observe a sharper increase in career breaks 
due to parental leave, from around 5 to 10 months in the 1980s to between 15 and 20 months (and over 25 months in one estimate) in the 1990s.

Thus, Fig. 1 suggests that, ceteris paribus, mothers' labor force attachment decreases through the direct effect of parental leave extension, in particular for those women who return to the labor force within the first 3 years after childbirth and are thus more attached to labor market than mothers who quit the labor market for more years. As it is difficult for employers to predict who will become a mother and when, all else being equal, the extension of the leave period has probably decreased the expected job attachment of all female employees at childbearing age, even though, as discussed later in Section 3, other factors besides parental leave expansion might be impacting the labor supply of young women. Note, however, that birth rates did not rise. In the discussion paper version (Puhani and Sonderhof 2008), we show that birth rates declined somewhat, but not dramatically, during the observation period.

\section{Data and methodology}

\subsection{The treatment group and datasets}

From the employer's perspective, extension of the parental leave period de facto constitutes an increase in employment protection for women of childbearing age. That is, if increased protection rights for young women are not reflected in implicit or explicit contracts that compensate employers for young women's extended parental leave, women of childbearing age can expect diminished employment opportunities, such as less job-related training (Lazear 1990). However, unlike Schönberg and Ludsteck (2007), who consider extended parental leave a treatment for mothers only and use mothers subject to shorter parental leave as controls to measure labor force participation and wages as outcomes, we are interested in extended parental leave rights as a treatment that affects all women of childbearing age with job-related training as an outcome of that treatment. Therefore, in our research design, the treatment group consists of all women of childbearing age, defined as those between 20 and 35 years of age. We exclude women between 36 and 39 years of age because we cannot tell whether or not an employer perceives these women as being of childbearing age. ${ }^{6}$

In the subsequent analysis, we draw on three individual-level datasets that represent the West German workforce. East Germany is excluded because at the time of the reform; it was experiencing a major transition whose related

\footnotetext{
${ }^{6}$ According to administrative birth records for Germany, 8.3 percent of all new mothers in 1990 were 36 years of age or older. This share is rising over time. For example, in the year 2000, it was already 11.5 percent. However, the share of all new mothers aged 40 or older is much lower at 1.8 and 2.5 percent in the years 1990 and 2000, respectively.
} 
factors are difficult to filter out from the effect of the parental leave extension. In addition, the pre-reform points of observation are mostly from the 1980s when East Germany was under communist rule and thus excluded from the data. The three datasets used are the Report System [on] Further Education (Berichtssystem Weiterbildung (BSW) survey years 1988, 1994, 1997, and 2003), ${ }^{7}$ the GSOEP (survey years 1989, 2000, and 2004), ${ }^{8}$ and the Qualification and Careers Survey (Qualifikation und Berufsverlauf, IAB-BIBB, survey years 1991 and 1998). ${ }^{9}$ A brief description of the datasets with summary statistics can be found in Appendices 1 and 2.

We restrict the sample to persons who are currently employed and, hence, attached to the labor market because by definition, persons not working cannot receive job-related training. Hence, we ignore the potential effect of extended parental leave on training that works directly through (temporarily) reduced labor supply in order to focus on the effect for young women attached to the labor market (and thus potentially interested in job-related training). ${ }^{10}$ Nevertheless, because the three datasets we use measure the incidence of past job-related training for the last 1, 3, and 5 years (BSW, GSOEP, and IAB$\mathrm{BIBB}$, respectively), in two of the datasets, we cannot avoid capturing some of the potential direct effect through the reduced labor supply that results from parental leave.

Despite differences in the size of the event window referred to by the various surveys, all three datasets exhibit a large degree of communality in training incidence, with training participation in the BSW and GSOEP varying between a quarter and a third (see Table 2). In the IAB-BIBB data, participation is somewhat higher (between a third and almost one half) because this survey asks for training during the previous 5 years (compared to 1 year in the BSW and 3 years in the GSOEP).

As Table 2 shows, all datasets report an increase in training participation over time, a finding that holds true for all age-gender groups. Moreover, consistent with the growing emphasis on lifelong learning, training participation increased more among older (aged 40-55) than younger workers (aged 20-35). Note, however, that in 1994, after the extension of parental leave, young women had the lowest incidence of employer-arranged training but the

\footnotetext{
${ }^{7}$ More information on these data is available from the Central Archive for Empirical Social Research, University of Cologne, web site: http://info1.za.gesis.org/DBKSearch12/SDesc.asp.

${ }^{8}$ The GSOEP is probably the most frequently used individual-level dataset for Germany. For more information, see http://www.diw.de/english/soep/29012.html.

${ }^{9}$ The Qualification and Careers Survey (IAB-BIBB), which specializes in job descriptions, was also used by Spitz-Öner (2006). More information is available at http://www.gesis.org/ Datenservice/Themen/38Beruf.htm.

${ }^{10}$ According to OECD statistics, the labor force participation rate of women in Germany is somewhat below the rate in the U.S., namely at 63.6 and 70.8 percent in the year 2000 , respectively. By 2008 , these figures virtually equalized, however, at 70.3 and 70.4 percent for Germany and the U.S., respectively.
} 
Table 2 Descriptive statistics: training participation

\begin{tabular}{|c|c|c|c|c|c|c|c|c|c|c|}
\hline & \multicolumn{6}{|c|}{ BSW data } & \multicolumn{4}{|c|}{ Other datasets } \\
\hline & \multicolumn{2}{|c|}{$\begin{array}{l}\text { Job-related } \\
\text { training } \\
\text { (general) }\end{array}$} & \multicolumn{2}{|c|}{$\begin{array}{l}\text { Job-related } \\
\text { training } \\
\text { (employer- } \\
\text { arranged) }\end{array}$} & \multicolumn{2}{|c|}{$\begin{array}{l}\text { Job-related } \\
\text { training } \\
\text { (own } \\
\text { initiative) }\end{array}$} & \multicolumn{2}{|c|}{$\begin{array}{l}\text { GSOEP } \\
\text { (general) }\end{array}$} & \multicolumn{2}{|c|}{$\begin{array}{l}\text { IAB-BIBB } \\
\text { (general) }\end{array}$} \\
\hline & 1988 & 1994 & 1988 & 1994 & 1988 & 1994 & 1989 & 2000 & 1991 & 1998 \\
\hline All & 0.26 & 0.34 & 0.14 & 0.19 & 0.12 & 0.14 & 0.30 & 0.36 & 0.35 & 0.42 \\
\hline Young women & 0.26 & 0.30 & 0.13 & 0.15 & 0.13 & 0.16 & 0.31 & 0.35 & 0.33 & 0.37 \\
\hline Older women & 0.18 & 0.31 & 0.09 & 0.16 & 0.10 & 0.14 & 0.16 & 0.34 & 0.26 & 0.39 \\
\hline Young men & 0.32 & 0.36 & 0.16 & 0.22 & 0.15 & 0.14 & 0.38 & 0.38 & 0.37 & 0.39 \\
\hline Older men & 0.25 & 0.36 & 0.16 & 0.22 & 0.08 & 0.14 & 0.32 & 0.37 & 0.39 & 0.51 \\
\hline$n$ & 3,112 & 2,147 & 3,112 & 2,147 & 3,112 & 2,147 & 2,764 & 5,639 & 16,682 & 17,564 \\
\hline
\end{tabular}

The figures indicate the share of people who participated in training in the previous year, the previous 3 years, and the previous 5 years in the BSW, GSOEP, and IAB-BIBB data, respectively. Source: Report System Further Education (BSW); German Socio-Economic Panel (GSOEP); Qualification and Careers (IAB-BIBB); own calculations

highest incidence of training on the employee's initiative. ${ }^{11}$ Neither of these facts held in 1988, before the extension of parental leave. Of course, these are point estimates from samples and not all of the differences between groups and across time are statistically significant (not shown here). However, formal testing of the before-after comparisons is carried out in Section 4.

\subsection{Potential control groups}

In tracking the development of job-related training of young women before and after the increase in the parental leave period, we consider three demographic groups to construct control group designs: young men of similar age to the treatment group (20-35), women aged 40-55 years, and young men together with women and men aged 40-55. Similar treatment-control group designs are used in Gruber (1994), Ruhm (1998), Waldfogel (1999), and Lai and Masters (2005). We exclude persons older than 55 years from all analyses because this group's outcomes may be affected by other factors like early retirement, which may evolve differentially between men and women. In addition, training is less important to the older worker because the closer the retirement age, the lower the returns to investment.

Before comparing changes in training participation before and after the parental leave extension for different age-gender groups, we check whether

\footnotetext{
${ }^{11}$ The question in the BSW asks whether job-related training was a) arranged by the company, b) arranged on the recommendation of a supervisor, or c) on your own initiative. We subsume answers a) and b) under 'employer-arranged training' in contrast to 'training on one's own initiative'.
} 
the extension of the parental leave (and benefit) period did indeed lower young women's labor market attachment in relation to the potential control groups. This assessment is important because theory suggests that labor market attachment may be a key determinant of employers' willingness to support jobrelated training (Hashimoto 1981). Likewise, observation of young women's labor force participation is important because general trends in female labor force participation may overlap with the effects of parental leave on labor force participation and thus also influence job-related training. Hence, we must show an association between the German government's extension of parental leave duration and a decrease in young women's labor force participation relative to the control group. As Fig. 1 has already shown, for young mothers, actual parental leave periods have increased.

Figure 2 profiles the development of the full-time equivalent labor force participation rates of our treatment group (young women, irrespective of whether they are mothers) in relation to various control group designs. Because we restrict our sample to employees, self-employed are excluded; however, the

(a)

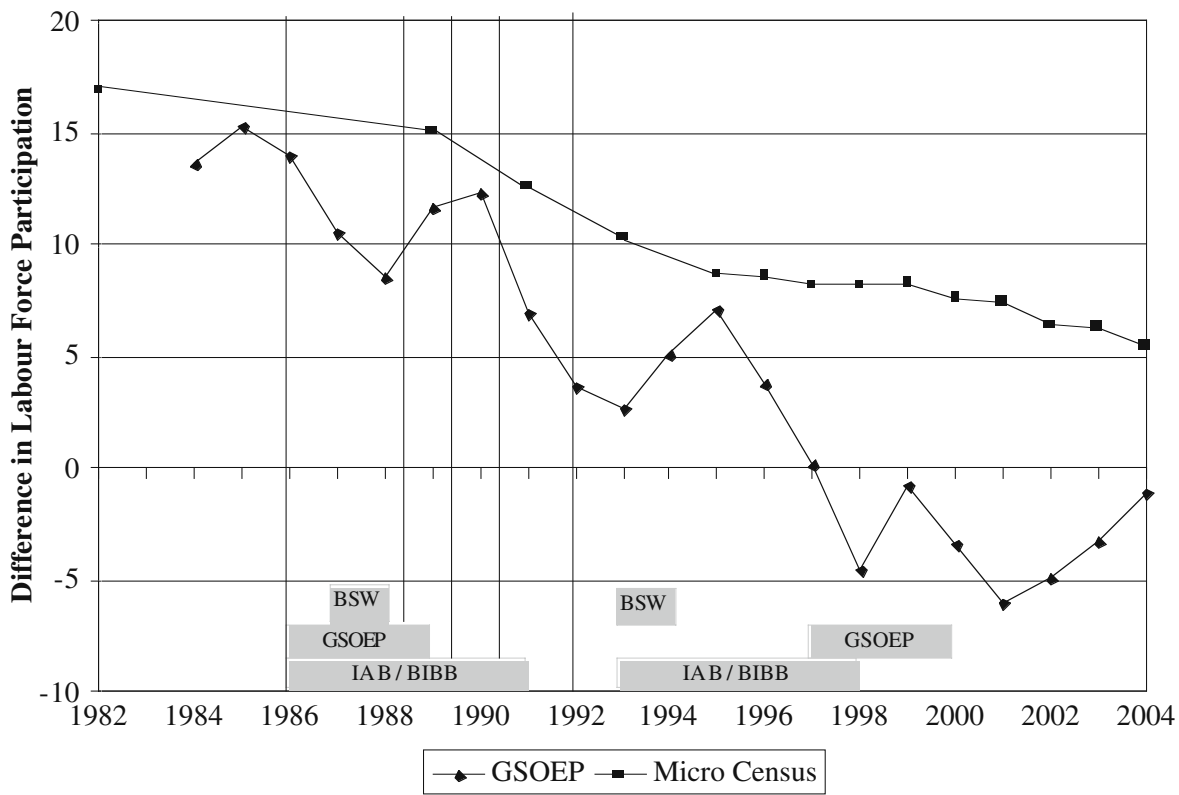

Fig. 2 Changes in young women's relative labor force participation-full-time equivalents. a Using older women as a comparison. b Using young men as a comparison. c Difference in differences between young and older persons' labor force participation between men and women. The boxes at the bottom of the graphs indicate the event windows referred to in the training questions in the respective surveys. As mentioned in the text, the BSW refers to job-related training in the previous year, whereas the GSOEP and IAB-BIBB data refer to the previous 3 and 5 years, respectively. Vertical lines show the timing of the reforms to increase parental leave duration. Source: Micro Census (MZ); German Socio-Economic Panel (GSOEP); own calculations 
(b)

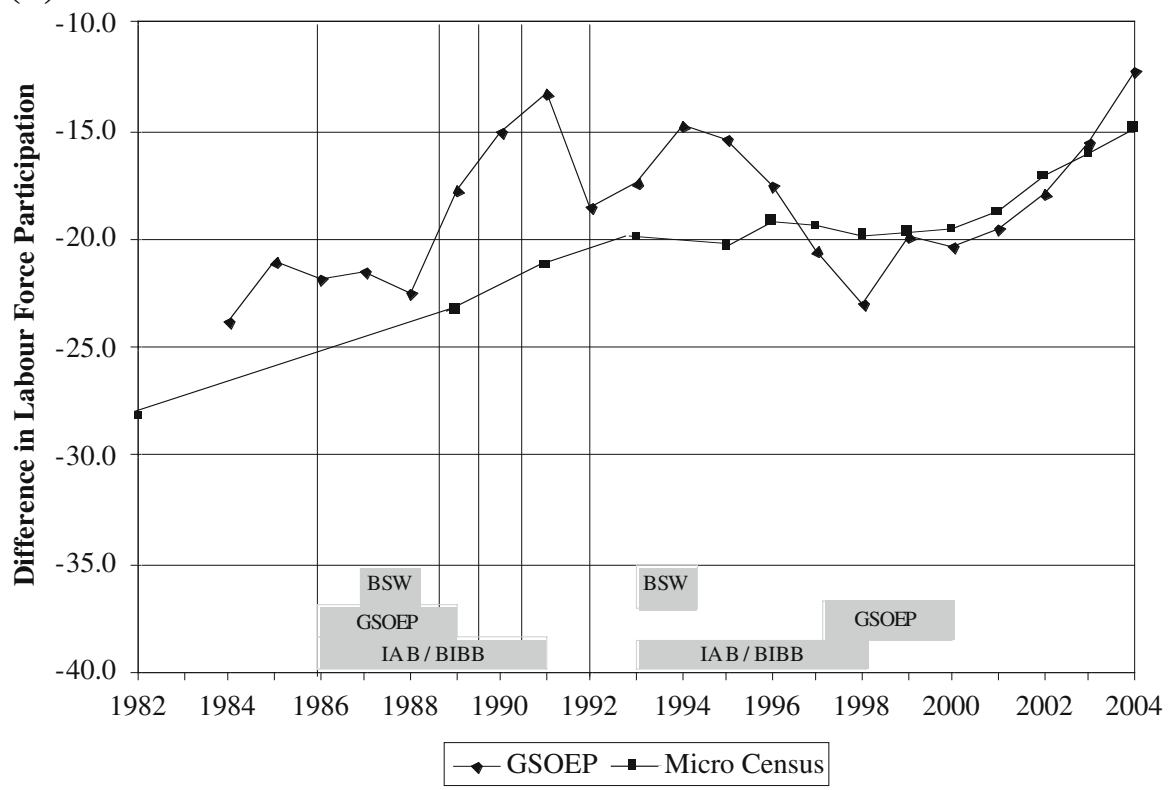

(c)

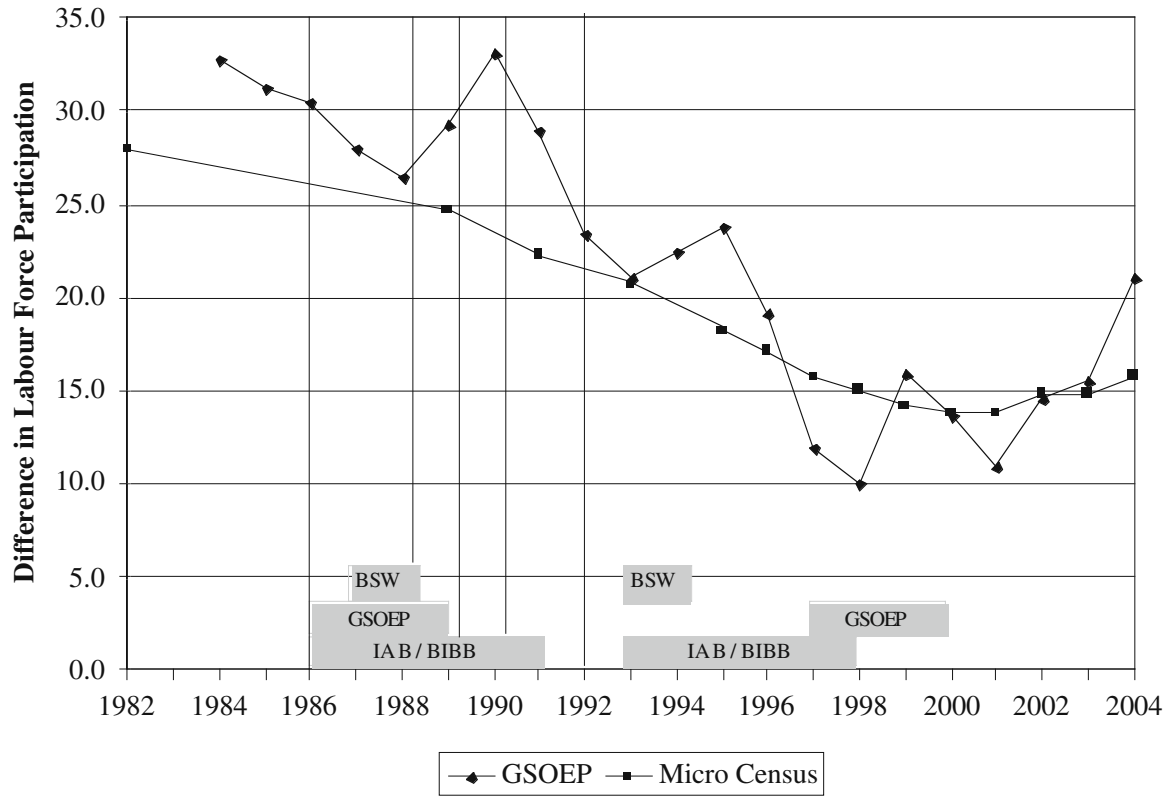

Fig. 2 (continued) 
graphs are robust to the inclusion of self-employed workers. ${ }^{12}$ The datasets we can use to track labor force participation across time are the GSOEP and the German Micro Census. ${ }^{13}$

We expect no abrupt change in labor market participation owing to parental leave extension because hesitation to exploit the extended leave to its full extent is quite plausible in the face of uncertainty about how the employer will deal with this new situation. This view is borne out by the gradual increase in the average parental leave period exhibited in Fig. 1.

Figure 2 shows that young women's labor force participation decreased relative to the rate of older women (panel a), as did the gap between young and older women relative to the rate between young and older men (panel c). In addition, especially in panel (a), this decrease is most pronounced during the period when parental leave was extended. However, young women's labor force participation actually increased relative to that of young men (panel b) ${ }^{14}$ Therefore, there must have been other factors generating a trend rise in young women's labor force participation relative to their male peers unrelated to the parental leave extension and thus make young men an inappropriate control group for a simple difference-in-differences design. In other words, we expect that young women's job-related training incidence would have risen relative to the training incidence of young men because of this confounding trend in relative labor force participation unrelated to the policy reform. Because this would invalidate the identification assumption of the differencein-differences estimator, we do not use young men as a control group in the simple difference-in-differences estimates. ${ }^{15}$ However, apart from simple difference-in-differences, we also estimate difference-in-differences models

\footnotetext{
${ }^{12}$ There are different regulations for civil servants when it comes to unpaid leave (whether for parental or other reasons) with a right to return. They can take up to 12 (15 since February 2009) years of leave and this was left unchanged by the reform discussed here as far as the extension of the parental leave duration is concerned. However, civil servants were affected by the extension of the duration of parental benefit payments just as other employees. Point estimates for the sample excluding civil servants are comparable to (in fact a bit higher than) the ones including civil servants, but standard errors are also higher. Therefore, and because we want to estimate the effect for the entire West German workforce, we do not exclude civil servants from our sample.

${ }^{13}$ The Micro Census (MZ) is a one-percent sample of the population (the scientific community receives only a 70 percent sample of that one percent) and asks questions similar to a census. For political reasons, there has been no census in Germany since 1987, so the Micro Census acts as a substitute. For more information, see http://www.destatis.de/jetspeed/portal/cms/Sites/ destatis/Internet/EN/press/abisz/Mikrozensus_e,templateId=renderPrint.psml.

${ }^{14}$ Nevertheless, the Micro Census data clearly suggest that the long-run trend in catching up with young men stalled after 1992 (when the parental leave period was doubled from 18 to 36 months) until about 2000. Hence, the short time series presented here is consistent with a permanent reduction in the labor force attachment of young women relative to their male peers.

${ }^{15}$ In results not shown here, it turns out, however, that despite of the catch-up in labor supply of young women in relation to young men, young women have lost in terms of employer-arranged training in relation to young men after the extension of parental leave. When considering training in general, however, they have caught up. Yet, consistent with the relative labor supply trends shown here, this catch-up in terms of training in general was slowed down in the period when parental leave was extended (compared to a placebo period).
} 
accounting for group-specific trends when more than two waves of data are available. In this case, we can also use young men as a control group, because any confounding group-specific trends are controlled for as long as they are (approximately) linear.

\subsection{Estimating equations}

Based on the control group designs just presented, we estimate five sets of regression equations. The first is an estimate of the difference in training incidence between young and older women before and after the 1992 reform:

$$
\text { training }_{i t}=\alpha+\beta_{1} X_{i t}+\beta_{2} \text { after }_{i t}+\beta_{3} \text { young }_{i t}+\tau_{1}\left(\text { young }_{i t} \times \text { after }_{i t}\right)+\varepsilon_{i t}
$$

where training is an indicator variable that is equal to 1 if training has occurred. "Young" and "after" are dummy variables indicating whether a woman is young (20 to 35 years) and whether an observation refers to a post-1992 point in time. The vector $X$ denotes other control variables. In this difference-indifferences setup, the effect of interest is $\tau_{1}$, which we expect to be negative because of the relative labor supply developments shown in Fig. 2. When we have panel data (as in the GSOEP) instead of repeated cross sections (as in the other two datasets), we adjust standard errors for clustering (Bertrand et al. 2004).

When older women and young and older men are used as controls, we estimate a difference-in-difference-in-differences model using the following equation:

$$
\begin{aligned}
\text { training }_{i t}= & \alpha+\beta_{1} X_{i t}+\beta_{2} \text { after }_{i t}+\beta_{3} \text { female }_{i t}+\beta_{4} \text { young }_{i t} \\
& +\beta_{5}\left(\text { female }_{i t} \times \text { young }_{i t}\right)+\beta_{6}\left(\text { female }_{i t} \times \text { after }_{i t}\right)+\beta_{7}\left(\text { young }_{i t} \times \text { after }_{i t}\right) \\
& +\tau_{2}\left(\text { female }_{i t} \times \text { young }_{i t} \times \text { after }_{i t}\right)+\varepsilon_{i t}
\end{aligned}
$$

with $\tau_{2}$ as the coefficient of interest, which, as argued in relation to Fig. 2, is expected to be negative. When estimating models (1) and (2), we can make use of all three datasets with the pre- and post-reform survey years 1988 and 1994 for the BSW, 1989 and 2000 for the GSOEP, and 1991 and 1998 for the IAB-BIBB.

As two of our datasets allow us to use more than 2 years of data (BSW: 1988, 1994, 1997, 2003; GSOEP: 1989, 2000, 2004), we can use the additional years for an identification strategy that allows for group-specific trends and identifies the treatment effect on the treated as the difference in the trend shifts after the reform between the treatment and control group. So when older women are the control group, the estimating equation becomes

$$
\begin{aligned}
\operatorname{training}_{i t}= & \alpha+\beta_{1} X_{i t}+\beta_{2} \text { after }_{i t}+\beta_{3} \text { young }_{i t}+\gamma_{1} t+\gamma_{2}\left(t \times \text { young }_{i t}\right) \\
& +\tau_{3}\left(\text { young }_{i t} \times \text { after }_{i t}\right)+\varepsilon_{i t} .
\end{aligned}
$$

where $t$ is the time trend and $\tau_{3}$ the coefficient of interest. Because the difference-in-trend-shifts estimator allows for group-specific trends, we can, 
in this case, also use young men as a control group for young women, so that another estimating equation becomes

$$
\begin{aligned}
\operatorname{training}_{i t}= & \alpha+\beta_{1} X_{i t}+\beta_{2} \text { after }_{i t}+\beta_{3} \text { female }_{i t}+\gamma_{1} t+\gamma_{2}\left(t \times \text { female }_{i t}\right) \\
& +\tau_{4}\left(\text { female }_{i t} \times \text { after }_{i t}\right)+\varepsilon_{i t}
\end{aligned}
$$

where only young women and men are in the sample. Finally, this approach can be extended to a difference-in-differences-in-trend-shifts identification strategy, where the control group design is jointly built by older women and young and older men:

$$
\begin{aligned}
\operatorname{training}_{i t}= & \alpha+\beta_{1} X_{i t}+\beta_{2} \text { after }_{i t}+\beta_{3} \text { female }_{i t}+\beta_{4} \text { young }_{i t} \\
& +\beta_{5}\left(\text { female }_{i t} \times \text { young }_{i t}\right)+\beta_{6}\left(\text { female }_{i t} \times \text { after }_{i t}\right)+\beta_{7}\left(\text { young }_{i t} \times \text { after }_{i t}\right) \\
& +\gamma_{1} t+\gamma_{2}\left(t \times \text { female }_{i t}\right)+\gamma_{3}\left(t \times \text { young }_{i t}\right)+\gamma_{4}\left(t \times \text { female }_{i t} \times \text { young }_{i t}\right) \\
& +\tau_{5}\left(\text { female }_{i t} \times \text { young }_{i t} \times \text { after }_{i t}\right)+\varepsilon_{i t}
\end{aligned}
$$

We have estimated results for four types of specifications. First, as would be appropriate if the before-after comparison was not confounded by any compositional effects or if any compositional effects were the outcome of extending the parental leave period, we have used no control variables (e.g., if young women invested less in education, education would be endogenous and thus should not be controlled for). We have then successively increased the set of control variables in specifications (2) through (4), first by including dummy variables for education (i.e., high school diploma/A-level/Abitur and a tertiary polytechnic or university degree) and controlling for age and age squared to account for possible changes in the age distributions within age groups. In specification (3), we have also added job characteristics using dummy variables for full-time, white-collar, and civil service employment. Finally, in specification (4), we have incorporated dummy variables for civil status (i.e., for being married and having children). Thus, those variables most likely to be endogenous have been included last in the four specifications. In other words, we believe that family status and children might be affected by extended parental leave, whose original intention was to facilitate more intensive childcare by the parents while not allowing the employer to terminate the employment relationship during this parental leave period. Some politicians hoped that these regulations might increase fertility. If family status variables und children were affected by the reform, it is not clear whether they should be included among the controls (although this depends upon the research question asked). Similar arguments might apply to the occupational and educational variables, but probably to a lesser extent. It has turned out that controlling for these sets of variables has only had a minor impact on the estimates. Since there are only minor differences between the four specifications, we only report estimates based on the specification with the full set of control variables in the subsequent tables (with one exception in Appendix 3). 


\section{Results}

\subsection{Before-after estimates by age and gender}

In Table 3, we formalize the comparison of changes in training incidence by providing before-after estimates for the four age-gender groups: young women as the treatment group and older women and young and older men as the controls. These estimates use the full set of control variables. Results showing the stepwise inclusion of all control variables are shown in Appendix 3.

As Table 3 shows, according to the BSW data, the smallest increase in training incidence between the 1988 and 1994 surveys (referring to training in 1987 and 1993, respectively) is among young women. That is, the point estimate in specification 4 exhibits an increase in training participation of 5.7 percentage

Table 3 Before-after estimates

\begin{tabular}{|c|c|c|c|c|c|}
\hline & \multicolumn{3}{|l|}{ BSW data } & \multicolumn{2}{|c|}{ Other datasets } \\
\hline & $\begin{array}{l}\text { Job-related } \\
\text { training } \\
\text { (general) }\end{array}$ & $\begin{array}{l}\text { Job-related } \\
\text { training } \\
\text { (employer- } \\
\text { arranged) }\end{array}$ & $\begin{array}{l}\text { Job-related } \\
\text { training } \\
\text { (own initiative) }\end{array}$ & $\begin{array}{l}\text { GSOEP } \\
\text { (general) }\end{array}$ & $\begin{array}{l}\text { IAB-BIBB } \\
\text { (general) }\end{array}$ \\
\hline $\begin{array}{l}\text { Young women } \\
\begin{array}{l}n=1,188 \\
n=1,716 \\
n=7,513\end{array}\end{array}$ & $\begin{array}{r}0.057^{\mathrm{a}} \\
(0.031)\end{array}$ & $\begin{array}{c}0.025 \\
(0.024)\end{array}$ & $\begin{array}{r}0.045^{\mathrm{a}} \\
(0.027)\end{array}$ & $\begin{array}{l}0.002 \\
(0.030)\end{array}$ & $\begin{array}{l}0.012 \\
(0.012)\end{array}$ \\
\hline $\begin{array}{l}\text { Older women } \\
\begin{array}{l}n=1,016 \\
n=1,849 \\
n=6,823\end{array}\end{array}$ & $\begin{array}{r}0.088^{c} \\
(0.029)\end{array}$ & $\begin{array}{c}0.073^{\mathrm{c}} \\
(0.022)\end{array}$ & $\begin{array}{r}0.047^{\mathrm{c}} \\
(0.023)\end{array}$ & $\begin{array}{l}0.128^{c} \\
(0.024)\end{array}$ & $(0.012)$ \\
\hline $\begin{array}{l}\text { Young men } \\
\begin{array}{c}n=1,405 \\
n=2,175 \\
n=9,560\end{array}\end{array}$ & $\begin{array}{c}0.061^{b} \\
(0.029)\end{array}$ & $\begin{array}{c}0.070^{c} \\
(0.025)\end{array}$ & $\begin{array}{c}0.010 \\
(0.024)\end{array}$ & $\begin{array}{l}-0.004 \\
(0.028)\end{array}$ & $\begin{array}{l}0.006 \\
(0.011)\end{array}$ \\
\hline $\begin{array}{l}\text { Older men } \\
n=1,456 \\
n=2,539 \\
n=10,072\end{array}$ & $\begin{array}{c}0.101^{\mathrm{c}} \\
(0.027)\end{array}$ & $\begin{array}{c}0.062^{\mathrm{c}} \\
(0.024)\end{array}$ & $\begin{array}{c}0.066^{\mathrm{c}} \\
(0.020)\end{array}$ & $\begin{array}{l}0.039^{\mathrm{a}} \\
(0.028)\end{array}$ & $\begin{array}{l}0.085^{\mathrm{c}} \\
(0.010)\end{array}$ \\
\hline
\end{tabular}

The estimates are based on regressions with the following set of control variables: age, age squared, dummy variables for high school (A-level, Abitur) and tertiary degrees, dummy variables for full-time employment, white-collar job, civil-service employment, for being married and for having children. Because control variables only have a minor impact on these estimates, we only report the results with the full set of controls here (see Appendix 3 for estimates without controls and estimates that include control variables stepwise). The numbers of observations refer to the samples of the three data sets, respectively. Source: Report System Further Education (BSW); German Socio-Economic Panel (GSOEP); Qualification and Careers (IAB-BIBB); own calculations

${ }^{a}$ Significance at the $10 \%$ level

${ }^{\mathrm{b}}$ Significance at the $5 \%$ level

'Significance at the $1 \%$ level 
points, significant only at the $10 \%$ level, compared to a 6.1 percentage point estimate for young men, significant at the $5 \%$ level. The point estimates for older women and men are even larger and highly significant, at 8.8 and 10.1 percentage points, respectively.

Although the difference between the increases in training for young women and men seem rather small (5.7 versus 6.1 percentage points), this contrast becomes much more pronounced when we distinguish between different types of training (only possible consistently over time in the BSW data). Young women's probability to have taken part in employer-arranged training only increased by 2.5 percentage points (statistically insignificant); the number for young men, however, is 7.0 percentage points (significant at the $5 \%$ level). By contrast, young women seem to have partially compensated for this divergence by investing more in training on their own (rather than their employer's) initiative: the increases in the training incidences for this type of training are 4.5 percentage points for young women (significant at the $10 \%$ level), but only 1 percentage point for young men (insignificant).

Hence, overall, young women have not only experienced somewhat lower increases in training than young men but also a change in the type of training they receive in relation to young men: the before-after estimates suggest that employers were less interested in the training of young women in relation to young men after the extension of parental leave. What is striking is that the BSW data report similar (and significant) increases in employer-arranged training for three age-gender groups: young men (7.0 percentage points), older women (7.3 percentage points), and older men (6.2 percentage points), but not for young women (insignificant 2.5 percentage points). As a result, young women compensated this development by an increase in their own initiative to obtain training.

When comparing the BSW results with the other two datasets, we can only consider training incidence in general, but not by the type of training (employer-arranged or not). As can be seen in Table 3, similar to the BSW data, the GSOEP and the IAB-BIBB data show an increase in training of older relative to younger workers (irrespective of gender). Hence, the BSW data seem to measure the same thing as the other two datasets. However, they give better information on the type of training.

Note that for training arranged by the employer, the "age effect" in the increase in training is not observed any more (that is to say, although older workers have higher training in general increases than younger workers, they do not exhibit higher employer-arranged training increases than young workers). Because training arranged by the employer is more relevant than training in general, we will put special emphasis on the BSW data in the following, but use GSOEP and IAB-BIBB data for robustness checks.

\subsection{Difference-in-differences and difference-in-trend-shifts estimates}

As Table 4 demonstrates, job-related training is much more common among white-collar than among blue-collar workers (e.g., 33\% versus $13 \%$ in the 1988 
Table 4 Training participation for subgroups

\begin{tabular}{|c|c|c|c|c|c|c|}
\hline & $\begin{array}{l}\text { Blue-collar } \\
\text { workers }\end{array}$ & $\begin{array}{l}\text { White-collar } \\
\text { workers }\end{array}$ & $\begin{array}{l}\text { In firms with } \\
\text { less than } 20 \\
\text { employees }\end{array}$ & $\begin{array}{l}\text { In firms with } \\
\text { at least } 20 \\
\text { employees }\end{array}$ & $\begin{array}{l}\text { White-collar } \\
\text { workers and } \\
\text { less than } 20 \\
\text { employees }\end{array}$ & $\begin{array}{l}\text { White-collar } \\
\text { workers and } \\
\text { at least } 20 \\
\text { employees } \\
\end{array}$ \\
\hline $\begin{array}{l}\text { BSW- } \\
\text { (general) }\end{array}$ & 0.13 & 0.33 & 0.17 & 0.28 & 0.22 & 0.35 \\
\hline $\begin{array}{l}\text { BSW-(empl.- } \\
\text { arranged) }\end{array}$ & 0.08 & 0.18 & 0.07 & 0.16 & 0.09 & 0.20 \\
\hline $\begin{array}{r}\text { BSW-(own } \\
\text { initiative) }\end{array}$ & 0.05 & 0.15 & 0.09 & 0.12 & 0.12 & 0.15 \\
\hline SOEP & 0.13 & 0.41 & 0.16 & 0.34 & 0.20 & 0.45 \\
\hline IAB-BIBB & 0.20 & 0.44 & 0.25 & 0.37 & 0.29 & 0.48 \\
\hline
\end{tabular}

The figures indicate the share of people who participated in training in the previous year, the previous 3 years, and the previous 5 years in the 1998 BSW, 1989 GSOEP, and 1991 IAB-BIBB data, respectively. Source: Report System Further Education (BSW); German Socio-Economic Panel (GSOEP); Qualification and Careers (IAB-BIBB); own calculations

BSW survey). Among white-collar workers, training participation is higher in larger than in very small firms (35\% versus $22 \%$ in the $1988 \mathrm{BSW}$ survey), perhaps because the latter find it more difficult to substitute for workers who are currently in training. Parental leave reform might be more likely to have an impact on a group of workers with a high training incidence. ${ }^{16}$ We thus also report estimates where we restrict the sample to white-collar workers in firms with at least 20 employees to see whether the estimates for this subsample are more pronounced than those for all workers. Unfortunately, the information on firm size varies between datasets so that in the IAB-BIBB data, the firmsize limit must be set to 10 instead of 20 employees. In the BSW and GSOEP data, however, we are able to limit the sample to white-collar workers in firms with at least 20 employees. ${ }^{17}$

Table 5 presents the difference-in-differences and difference-in-trend-shifts estimates for the three datasets and the five different identification strategies discussed in Section 3. ${ }^{18}$

\footnotetext{
${ }^{16}$ For the same reason that larger firms might more easily find substitutes for women on leave, extension of parental leave might also have a smaller effect in larger firms. It is thus an empirical question whether the effect is really larger in larger firms, where training incidence is higher.

${ }^{17}$ We have also checked whether the reform affected the selection into white-collar jobs at larger firms. To this end, we regressed an indicator for being a white-collar worker in a larger firm on the treatment indicator and all other control variables using all five control group designs described in the previous section. It turned out that the parental leave extension had no significant effect on the selection into white-collar jobs at larger firms: all point estimates were insignificant. Most point estimates were also close to zero.

${ }^{18}$ Again, because control variables do not make a noteworthy difference to the estimates, we only report the specifications for the full set of control variables.
} 
Table 5 Difference-in-differences and difference-in-trend-shifts estimates

\begin{tabular}{|c|c|c|c|c|c|}
\hline & $\begin{array}{l}\text { DiD } \\
\text { Contr. group: } \\
\text { older women }\end{array}$ & $\begin{array}{l}\text { DiDiD } \\
\text { Contr. group: } \\
\text { older women } \\
\text { and all men }\end{array}$ & $\begin{array}{l}\text { DiTS } \\
\text { Contr. group: } \\
\text { older women }\end{array}$ & $\begin{array}{l}\text { DiTS } \\
\text { Contr. group: } \\
\text { young men }\end{array}$ & $\begin{array}{l}\text { DiDiTS } \\
\text { Contr. group: } \\
\text { older women } \\
\text { and all men }\end{array}$ \\
\hline \multicolumn{6}{|l|}{ BSW } \\
\hline Full sample & $\begin{array}{r}-0.049 \\
(0.042)\end{array}$ & $\begin{array}{r}-0.018 \\
(0.057)\end{array}$ & $\begin{array}{r}-0.045 \\
(0.063)\end{array}$ & $\begin{array}{r}-0.004 \\
(0.063)\end{array}$ & $\begin{array}{l}0.056 \\
\quad(0.086)\end{array}$ \\
\hline Relative effect & -0.19 & -0.07 & -0.17 & -0.02 & 0.21 \\
\hline$n$ & 2,204 & 5,065 & 4,021 & 4,252 & 8,801 \\
\hline $\begin{array}{l}\text { White-collar } \\
\text { workers and at } \\
\text { least } 20 \text { employees }\end{array}$ & $\begin{array}{c}-0.067 \\
(0.059)\end{array}$ & $\begin{array}{r}-0.087 \\
(0.082)\end{array}$ & $\begin{array}{r}-0.090 \\
(0.081)\end{array}$ & $\begin{array}{r}-0.027 \\
(0.088)\end{array}$ & $\begin{array}{r}-0.047 \\
\quad(0.117)\end{array}$ \\
\hline Relative effect & -0.20 & -0.26 & -0.28 & -0.08 & -0.14 \\
\hline$n$ & 1,378 & 2,873 & 2,950 & 2,571 & 5,637 \\
\hline \multicolumn{6}{|l|}{ GSOEP } \\
\hline Full sample & $\begin{array}{r}-0.135^{\mathrm{c}} \\
(0.038)\end{array}$ & $\begin{array}{l}-0.055 \\
(0.052)\end{array}$ & $\begin{array}{r}-0.263^{\mathrm{b}} \\
(0.127)\end{array}$ & $\begin{array}{c}-0.154 \\
(0.138)\end{array}$ & $\begin{array}{r}-0.140 \\
(0.172)\end{array}$ \\
\hline Relative effect & -0.44 & -0.18 & -0.85 & -0.50 & -0.45 \\
\hline$n$ & 3,508 & 8,146 & 5,524 & 5,481 & 12,499 \\
\hline $\begin{array}{l}\text { White-collar } \\
\text { workers and at } \\
\text { least } 20 \text { employees }\end{array}$ & $\begin{array}{r}-0.218^{\mathrm{c}} \\
(0.056)\end{array}$ & $\begin{array}{r}-0.146^{\mathrm{a}} \\
(0.080)\end{array}$ & $\begin{array}{r}-0.373^{\mathrm{b}} \\
(0.177)\end{array}$ & $\begin{array}{c}-0.151 \\
(0.198)\end{array}$ & $\begin{array}{r}-0.216 \\
(0.250)\end{array}$ \\
\hline Relative effect & -0.51 & -0.34 & -0.87 & -0.35 & -0.50 \\
\hline$n$ & 1,991 & 4,362 & 3,192 & 2,833 & 6,793 \\
\hline \multicolumn{6}{|l|}{ IAB-BIBB } \\
\hline Full sample & $\begin{array}{r}-0.096^{\mathrm{c}} \\
(0.017)\end{array}$ & $\begin{array}{r}-0.020 \\
(0.022)\end{array}$ & & & \\
\hline Relative effect & -0.29 & -0.06 & & & \\
\hline$n$ & 14,336 & 33,968 & & & \\
\hline $\begin{array}{l}\text { White-collar } \\
\text { workers and at } \\
\text { least } 10 \text { employees }\end{array}$ & $\begin{array}{r}-0.131^{\mathrm{c}} \\
(0.024)\end{array}$ & $\begin{array}{c}-0.049 \\
(0.032)\end{array}$ & & & \\
\hline $\begin{array}{l}\text { Relative effect } \\
n\end{array}$ & $\begin{array}{l}-0.31 \\
8,448\end{array}$ & $\begin{array}{l}-0.11 \\
18,216\end{array}$ & & & \\
\hline
\end{tabular}

The estimates are based on regressions with the following set of control variables: age, age squared, dummy variables for high school (A-level, Abitur) and tertiary degrees, dummy variables for fulltime employment, white-collar job, civil-service employment, for being married and for having children. Because control variables only have a minor impact on these estimates, we only report the results with the full set of controls. Source: Report System Further Education (BSW); German Socio-Economic Panel (GSOEP); Qualification and Careers (IAB-BIBB); own calculations $D i D$ difference-in-differences; $D i D i D$ difference-in-difference-differences; DiTS difference-intrend-shifts; DiDiTS difference-in-difference-in-trend-shifts

${ }^{a}$ Significance at the $10 \%$

${ }^{\mathrm{b}}$ Significance at the $5 \%$

${ }^{\mathrm{c}}$ Significance at the $1 \%$

The estimates show a remarkable similarity across specifications and across datasets: all point estimates are negative (with one exception). Several, but not all, estimates are statistically significantly different from zero. Taking into account the standard errors of the estimates, it is particularly striking how 
similar the point estimates are across the five different identification strategies once the sample is restricted to white-collar workers in larger firms.

As argued in connection with relative labor supply developments (see Section 3), we expect young women to lose in terms of training incidence relative to older women because of the (accelerated) decrease in their labor supply after parental leave was extended. The difference-in-differences point estimates in Table 5 (first column) generally confirm this hypothesis, and the findings are statistically significant for two of the three datasets (GSOEP and IAB-BIBB). The point estimates are $-4.9,-13.5$, and -9.6 percentage points for the BSW, GSOEP, and IAB-BIBB datasets, respectively, implying that young women receive between 4.9 and 13.5 percentage points less training after the reform. By restricting the sample to white-collar workers in larger firms, point estimates become larger at $-6.7,-21.8$, and -13.1 in the three datasets. The difference-in-trend-shifts estimates-both with older women or younger men as the control group (columns three and four)-are also consistently negative and once one takes into account the larger standard errors associated with this identification strategy; these estimates confirm the findings from difference-in-differences.

Additionally, because average training participation differs between datasets and samples, we also provide estimates of the change in training participation for young women relative to the pre-reform level. The resulting estimates imply a relative decline in training participation by $20 \%, 44 \%$, and $29 \%$ for the difference-in-differences estimates in the BSW, GSOEP, and IAB-BIBB datasets, respectively (first column). When restricted to whitecollar workers in firms with at least 20 employees, the relative decline is even a bit larger at $19 \%, 51 \%$, and $31 \%$ in the BSW, GSOEP, and IAB-BIBB datasets, respectively. Especially large and significant are the estimates in those datasets that refer to a longer event window, i.e., training in the previous 3 and 5 years (the GSOEP and IAB-BIBB, respectively).

As pointed out previously, the longer the event window, the larger the estimates will be in absolute value in that they include the direct effect of prolonged parental leave on job-related training through temporary reduction of the labor supply due to parental leave. Moreover, although the BSW, which only refers to the previous year, also suggests a large effect (a 19\% reduction in job-related training for young women in comparison to older women, and similarly a $20 \%$ reduction when the sample is restricted to white-collar workers in larger firms), the coefficient estimates are not significant. Therefore, we interpret these estimates as only tentative evidence that extended parental leave reduces the incidence of job-related training for young women in general. Below, we will see that there is ample evidence that employer-arranged training has been reduced.

In the set of estimates using older women and young and older men as controls, in column two of Table 5, we employ a difference-in-difference-indifferences strategy to compare the changes in training incidence of young versus older women in relation to the changes of young versus older men. Based on the relative labor supply behavior reported earlier (see Fig. 2), 
we expect negative estimates for $\tau_{2}$, a hypothesis confirmed by all point estimates. For the BSW, GSOEP, and IAB-BIBB datasets, respectively, the point estimates suggest a $-1.8,-5.5$, and -2.0 percentage point change in young women's training participation. The estimates are not statistically significant. When restricted to white-collar workers in firms with at least 20 employees, the corresponding estimates are -8.7, -14.6 (significant at the $10 \%$ level), and -4.9 in the BSW, GSOEP, and IAB-BIBB datasets, respectively. Again, the corresponding difference-in-differences-in-trend-shifts estimates in column five are somewhat similar, albeit with larger standard errors.

Note that the just presented investigation of the impact of parental leave reform on the incidence of any job-related training makes no distinction between types of training, which, unlike schooling, is poorly classified in most surveys. Nevertheless, unlike the other two datasets, the BSW data have information on whether training was arranged directly by the employer or taken on the employee's own initiative (information lacking in the other datasets). ${ }^{19}$ In the following, we, therefore, apply the same estimates as above but distinguish between different types of training.

\subsection{Employer-arranged training versus training on the worker's initiative}

Only the BSW data provide information on the role of the employer in jobrelated training. Here, training incidence can be split up into training arranged by the employer and training on one's own initiative. We might expect that the extension of parental leave predominantly reduced the former type of training. The incidence of the two types of training for the four age-gender groups in the BSW data is reported in Table 2. Whereas in the first year of observation (1988), 26\% of all workers in the sample received some type of job-related training, only $14 \%$ received training arranged by the employer.

Table 6 shows estimation results for training in general as well as separate estimates for training arranged by the employer and on one's own initiative using the same control group designs as before. Again, we report two blocks of estimates, one for the full sample and one for white-collar workers in firms with at least 20 employees.

What is again striking is that for all five identification strategies, the point estimates for white-collar workers in larger firms are within the same ballpark, irrespective of whether they are statistically significant or not. The fact that several estimates are statistically insignificant may be due to the small sample size. However, it should be noted that all point estimates for employerarranged training are negative. For the subsample of white-collar workers in larger firms the majority of the estimates for employer-arranged training is statistically significant and negative; by contrast, all point estimates for training on the employee's initiative are positive (albeit mostly not statistically

\footnotetext{
${ }^{19}$ The GSOEP provides information on these training aspects, but the questions are not comparable across years.
} 
Table 6 Difference-in-differences and difference-in-trend-shifts estimates-results for different types of training-BSW

\begin{tabular}{|c|c|c|c|c|c|}
\hline & \multirow{2}{*}{$\begin{array}{l}\text { DiD } \\
\text { Contr. group: } \\
\text { older women }\end{array}$} & \multirow{2}{*}{$\begin{array}{l}\text { DiDiD } \\
\text { Contr. group: } \\
\text { older women } \\
\text { and all men }\end{array}$} & \multirow{2}{*}{$\begin{array}{l}\text { DiTS } \\
\text { Contr. group: } \\
\text { older women }\end{array}$} & \multirow{2}{*}{$\begin{array}{l}\text { DiTS } \\
\text { Contr. group: } \\
\text { young men }\end{array}$} & \multirow{2}{*}{$\begin{array}{l}\text { DiDiTS } \\
\text { Contr. group: } \\
\text { older women } \\
\text { and all men }\end{array}$} \\
\hline & & & & & \\
\hline \multicolumn{6}{|l|}{ Full sample } \\
\hline $\begin{array}{l}\text { Job-related training } \\
\text { (general) }\end{array}$ & $\begin{array}{l}-0.049 \\
(0.042)\end{array}$ & $\begin{array}{r}-0.018 \\
(0.057)\end{array}$ & $\begin{array}{r}-0.045 \\
(0.063)\end{array}$ & $\begin{array}{r}-0.004 \\
(0.063)\end{array}$ & $\begin{array}{l}0.056 \\
(0.086)\end{array}$ \\
\hline Relative effect & -0.19 & -0.07 & -0.17 & -0.02 & 0.21 \\
\hline $\begin{array}{c}\text { Job-related training } \\
\text { (empl.-arranged) }\end{array}$ & $\begin{array}{l}-0.046 \\
(0.033)\end{array}$ & $\begin{array}{r}-0.070 \\
(0.047)\end{array}$ & $\begin{array}{l}-0.070 \\
(0.052)\end{array}$ & $\begin{array}{r}-0.065 \\
(0.055)\end{array}$ & $\begin{aligned}-0.058 \\
(0.074)\end{aligned}$ \\
\hline Relative effect & -0.35 & -0.54 & -0.53 & -0.49 & -0.44 \\
\hline $\begin{array}{c}\text { Job-related training } \\
\text { (own initiative) }\end{array}$ & $\begin{array}{l}-0.003 \\
(0.035)\end{array}$ & $\begin{array}{l}0.049 \\
\quad(0.043)\end{array}$ & $\begin{array}{l}0.027 \\
\quad(0.050)\end{array}$ & $\begin{array}{l}0.059 \\
\quad(0.048)\end{array}$ & $\begin{array}{l}0.112^{\mathrm{a}} \\
\quad(0.066)\end{array}$ \\
\hline Relative effect & -0.02 & 0.38 & 0.21 & 0.45 & 0.86 \\
\hline$n$ & 2,203 & 5,065 & 4,021 & 4,252 & 8,801 \\
\hline \multicolumn{6}{|c|}{ White-collar workers in firms with at least 20 employees } \\
\hline $\begin{array}{l}\text { Job-related training } \\
\text { (general) }\end{array}$ & $\begin{array}{l}-0.067 \\
(0.059)\end{array}$ & $\begin{array}{r}-0.087 \\
(0.082)\end{array}$ & $\begin{array}{r}-0.090 \\
(0.081)\end{array}$ & $\begin{array}{r}-0.027 \\
(0.088)\end{array}$ & $\begin{aligned}-0.047 \\
(0.117)\end{aligned}$ \\
\hline Relative effect & -0.20 & -0.26 & -0.28 & -0.08 & -0.14 \\
\hline $\begin{array}{c}\text { Job-related training } \\
\text { (empl.-arranged) }\end{array}$ & $\begin{array}{r}-0.098^{\mathrm{b}} \\
(0.047)\end{array}$ & $\begin{array}{r}-0.157^{\mathrm{b}} \\
(0.071)\end{array}$ & $\begin{array}{r}-0.118^{\mathrm{a}} \\
(0.068)\end{array}$ & $\begin{array}{l}-0.099 \\
(0.080)\end{array}$ & $\begin{array}{r}-0.133 \\
(0.104)\end{array}$ \\
\hline Relative effect & -0.55 & -0.87 & -0.68 & -0.57 & -0.76 \\
\hline $\begin{array}{c}\text { Job-related training } \\
\text { (own initiative) }\end{array}$ & $\begin{array}{l}0.029 \\
\quad(0.050)\end{array}$ & $\begin{array}{l}0.065 \\
\quad(0.065)\end{array}$ & $\begin{array}{l}0.029 \\
\quad(0.066)\end{array}$ & $\begin{array}{l}0.068 \\
\quad(0.072)\end{array}$ & $\begin{array}{l}0.080 \\
\quad(0.095)\end{array}$ \\
\hline Relative effect & 0.19 & 0.43 & 0.19 & 0.45 & 0.53 \\
\hline$n$ & 1,378 & 2,873 & 2,950 & 2,571 & 5,637 \\
\hline
\end{tabular}

The estimates are based on regressions with the following set of control variables: age, age squared, dummy variables for high school (A-level, Abitur) and tertiary degrees, dummy variables for fulltime employment, white-collar job, civil-service employment, for being married and for having children. Source: Report System Further Education (BSW); own calculations

DiD difference-in-differences; DiDiD difference-in-difference-differences; DiTS difference-intrend-shifts; DiDiTS difference-in-difference-in-trend-shifts

${ }^{\text {a }}$ Significance at the $10 \%$

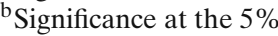

significant) but smaller in absolute size than the negative ones for employerarranged training. For employer-arranged training, the five-point estimates range between -9.8 and -15.7 percentage points. For training on one's own initiative, the estimates range between 2.9 and 8.0 percentage points. Hence, young women seem at best to have partially compensated for the decreased interest in their training by their employers.

In relation to the training incidence before parental leave extension, these point estimates are huge, implying a reduction in employer-arranged training of between $35 \%$ and $54 \%$ for all young women and between $55 \%$ and $87 \%$ for young white-collar women in firms with at least 20 employees. Moreover, estimated increases in training on the employee's initiative lie between $19 \%$ and $53 \%$ for this group of workers. We must not overemphasize these large numbers because of the large standard errors attached to the estimates. 
Nevertheless, point estimates are in a similar range irrespective of the control group chosen (for training on the employee's initiative this is only true if the sample is restricted to white-collar workers in larger firms).

Table 7 Difference-in-differences and difference-in-trend-shifts estimates for young women without children

\begin{tabular}{|c|c|c|c|c|c|}
\hline & $\begin{array}{l}\text { DiD } \\
\text { Contr. group: } \\
\text { older women }\end{array}$ & $\begin{array}{l}\text { DiDiD } \\
\text { Contr. group: } \\
\text { older women } \\
\text { and all men }\end{array}$ & $\begin{array}{l}\text { DiTS } \\
\text { Contr. group: } \\
\text { older women }\end{array}$ & $\begin{array}{l}\text { DiTS } \\
\text { Contr. group: } \\
\text { young men }\end{array}$ & $\begin{array}{l}\text { DiDiTS } \\
\text { Contr. group: } \\
\text { older women } \\
\text { and all men } \\
\end{array}$ \\
\hline \multicolumn{6}{|l|}{ BSW } \\
\hline Full sample & $\begin{array}{c}-0.069 \\
(0.049)\end{array}$ & $\begin{array}{c}-0.024 \\
(0.063)\end{array}$ & $\begin{array}{c}-0.079 \\
(0.076)\end{array}$ & $\begin{array}{r}-0.035 \\
(0.077)\end{array}$ & $\begin{array}{l}0.033 \\
(0.096)\end{array}$ \\
\hline Relative effect & -0.23 & $\begin{array}{l}-0.08 \\
4568\end{array}$ & -0.26 & -0.12 & 0.11 \\
\hline $\begin{array}{l}\text { White-collar } \\
\text { workers and at least } \\
20 \text { employees }\end{array}$ & $\begin{array}{r}-0.049 \\
(0.067)\end{array}$ & $\begin{array}{r}-0.060 \\
(0.088)\end{array}$ & $\begin{array}{l}-0.090 \\
(0.095)\end{array}$ & $\begin{array}{l}-0.031 \\
(0.101)\end{array}$ & $\begin{array}{r}-0.040 \\
(0.127)\end{array}$ \\
\hline Relative effect & -0.14 & -0.17 & -0.25 & -0.09 & -0.11 \\
\hline$n$ & 1,106 & 2,598 & 2,374 & 1,995 & 5,061 \\
\hline \multicolumn{6}{|l|}{ GSOEP } \\
\hline Full sample & $\begin{array}{c}-0.170^{\mathrm{c}} \\
(0.044)\end{array}$ & $\begin{array}{c}-0.088 \\
(0.057)\end{array}$ & $\begin{array}{r}-0.362^{\mathrm{b}} \\
(0.142)\end{array}$ & $\begin{array}{c}-0.237 \\
(0.153)\end{array}$ & $\begin{array}{l}-0.230 \\
(0.185)\end{array}$ \\
\hline Relative effect & -0.45 & -0.23 & -0.95 & -0.62 & -0.61 \\
\hline$n$ & 2,972 & 7,610 & 4,744 & 4,701 & 11,719 \\
\hline $\begin{array}{l}\text { White-collar } \\
\text { workers and at least } \\
20 \text { employees }\end{array}$ & $\begin{array}{r}-0.246^{\mathrm{c}} \\
(0.060)\end{array}$ & $\begin{array}{r}-0.173^{\mathrm{b}} \\
(0.083)\end{array}$ & $\begin{array}{r}-0.445^{\mathrm{b}} \\
(0.187)\end{array}$ & $\begin{array}{c}-0.201 \\
(0.209)\end{array}$ & $\begin{array}{r}-0.283 \\
(0.258)\end{array}$ \\
\hline Relative effect & -0.52 & -0.37 & -0.95 & -0.43 & -0.60 \\
\hline$n$ & 1,735 & 4,106 & 2,807 & 2,448 & 6,408 \\
\hline \multicolumn{6}{|l|}{ IAB-BIBB } \\
\hline Full sample & $\begin{array}{r}-0.103^{\mathrm{c}} \\
(0.019)\end{array}$ & $\begin{array}{c}-0.014 \\
(0.024)\end{array}$ & & & \\
\hline Relative effect & -0.28 & -0.04 & & & \\
\hline$n$ & 11,784 & 31,416 & & & \\
\hline $\begin{array}{l}\text { White-collar } \\
\text { workers and at least } \\
10 \text { employees }\end{array}$ & $\begin{array}{r}-0.133^{\mathrm{c}} \\
(0.026)\end{array}$ & $\begin{array}{r}-0.044 \\
(0.035)\end{array}$ & & & \\
\hline $\begin{array}{l}\text { Relative effect } \\
n\end{array}$ & $\begin{array}{l}-0.30 \\
7.101\end{array}$ & $\begin{array}{l}-0.10 \\
16.869\end{array}$ & & & \\
\hline
\end{tabular}

The estimates are based on regressions with the following set of control variables: age, age squared, dummy variables for high school (A-level, Abitur) and tertiary degrees, dummy variables for fulltime employment, white-collar job, civil-service employment, for being married and for having children. Because control variables only have a minor impact on these estimates, we only report the results with the full set of controls. Source: Report System Further Education (BSW); German Socio-Economic Panel (GSOEP); Qualification and Careers (IAB-BIBB); own calculations DiD difference-in-differences; DiDiD difference-in-difference-differences; DiTS difference-intrend-shifts; DiDiTS difference-in-difference-in-trend-shifts

${ }^{\text {a }}$ Significance at the $10 \%$

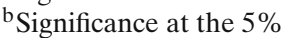

${ }^{\mathrm{c}}$ Significance at the $1 \%$ 


\subsection{Effects for young women without children}

Parental leave extension should affect women of childbearing age even if they currently do not have children because they are at risk of leaving the employer for up to 3 years with a right to return. This risk is enough to make them part of the treatment group. Therefore, to check whether the results so far also apply to women without children, we repeat the estimates provided in Tables 5 and 6 for young women who do not have children as treatment group (the control groups remain unchanged). These results, presented in Tables 7 and 8, show very similar point estimates to those obtained for the full samples, which include young women with children. Several estimates in

Table 8 Difference-in-differences and difference-in-trend-shifts estimates for young women without children - results for different types of training-BSW

\begin{tabular}{|c|c|c|c|c|c|}
\hline & $\begin{array}{l}\text { DiD } \\
\text { Contr. group: } \\
\text { older women }\end{array}$ & $\begin{array}{l}\text { DiDiD } \\
\text { Contr. group: } \\
\text { older women } \\
\text { and all men }\end{array}$ & $\begin{array}{l}\text { DiTS } \\
\text { Contr. group: } \\
\text { older women }\end{array}$ & $\begin{array}{l}\text { DiTS } \\
\text { Contr. group: } \\
\text { young men }\end{array}$ & $\begin{array}{l}\text { DiDiTS } \\
\text { Contr. group } \\
\text { older women } \\
\text { and all men }\end{array}$ \\
\hline \multicolumn{6}{|l|}{ Full sample } \\
\hline $\begin{array}{l}\text { Job-related training } \\
\text { (general) }\end{array}$ & $\begin{array}{r}-0.069 \\
(0.049)\end{array}$ & $\begin{array}{r}-0.024 \\
(0.063)\end{array}$ & $\begin{array}{r}-0.079 \\
(0.076)\end{array}$ & $\begin{array}{r}-0.035 \\
(0.077)\end{array}$ & $\begin{array}{l}0.033 \\
\quad(0.096)\end{array}$ \\
\hline Relative effect & -0.23 & -0.08 & -0.26 & -0.12 & 0.11 \\
\hline $\begin{array}{c}\text { Job-related training } \\
\text { (empl.-arranged) }\end{array}$ & $\begin{array}{l}-0.033 \\
(0.040)\end{array}$ & $\begin{array}{r}-0.056 \\
(0.052)\end{array}$ & $\begin{array}{r}-0.077 \\
(0.065)\end{array}$ & $\begin{array}{r}-0.076 \\
(0.067)\end{array}$ & $\begin{array}{r}-0.058 \\
(0.083)\end{array}$ \\
\hline Relative effect & -0.25 & -0.43 & -0.57 & -0.57 & -0.43 \\
\hline $\begin{array}{l}\text { Job-related training } \\
\text { (own initiative) }\end{array}$ & $\begin{array}{r}-0.035 \\
(0.039)\end{array}$ & $\begin{array}{l}0.029 \\
(0.048)\end{array}$ & $\begin{array}{r}-0.000 \\
(0.059)\end{array}$ & $\begin{array}{l}0.038 \\
\quad(0.059)\end{array}$ & $\begin{array}{l}0.087 \\
(0.073)\end{array}$ \\
\hline Relative effect & -0.22 & 0.22 & 0.00 & 0.23 & 0.53 \\
\hline$n$ & 1,712 & 4,568 & 3,172 & 3,403 & 7,953 \\
\hline \multicolumn{6}{|c|}{ White-collar workers in firms with at least 20 employees } \\
\hline $\begin{array}{l}\text { Job-related training } \\
\text { (general) }\end{array}$ & $\begin{array}{r}-0.049 \\
(0.067)\end{array}$ & $\begin{array}{r}-0.060 \\
(0.088)\end{array}$ & $\begin{aligned}-0.090 \\
(0.095)\end{aligned}$ & $\begin{array}{r}-0.031 \\
(0.101)\end{array}$ & $\begin{array}{r}-0.040 \\
\quad(0.127)\end{array}$ \\
\hline Relative effect & -0.14 & -0.17 & -0.25 & -0.09 & -0.11 \\
\hline $\begin{array}{l}\text { Job-related training } \\
\text { (empl-arranged) }\end{array}$ & $\begin{array}{r}-0.062 \\
(0.056)\end{array}$ & $\begin{array}{r}-0.123 \\
(0.077)\end{array}$ & $\begin{array}{r}-0.107 \\
(0.083)\end{array}$ & $\begin{array}{r}-0.098 \\
(0.093)\end{array}$ & $\begin{array}{r}-0.116 \\
(0.115)\end{array}$ \\
\hline Relative effect & -0.34 & -0.68 & -0.61 & -0.56 & -0.66 \\
\hline $\begin{array}{l}\text { Job-related training } \\
\text { (own initiative) }\end{array}$ & $\begin{array}{l}0.011 \\
\quad(0.053)\end{array}$ & $\begin{array}{l}0.057 \\
(0.069)\end{array}$ & $\begin{array}{l}0.016 \\
\quad(0.073)\end{array}$ & $\begin{array}{l}0.061 \\
(0.080)\end{array}$ & $\begin{array}{l}0.067 \\
(0.101)\end{array}$ \\
\hline Relative effect & 0.06 & 0.32 & 0.09 & 0.34 & 0.37 \\
\hline$n$ & 1,106 & 2,601 & 2,374 & 1,995 & 5,061 \\
\hline
\end{tabular}

The estimates are based on regressions with the following set of control variables: age, age squared, dummy variables for high school (A-level, Abitur) and tertiary degrees, dummy variables for fulltime employment, white-collar job, civil-service employment, for being married and for having children. Source: Report System Further Education

DiD difference-in-differences; DiDiD difference-in-difference-differences; DiTS difference-intrend-shifts; DiDiTS difference-in-difference-in-trend-shifts 
the GSOEP and IAB-BIBB samples are statistically significant, as shown in Table 7. However, as shown in Table 8, in the BSW estimates for different types of training, none of the estimates remain statistically significant once young women with children are excluded. However, the point estimates still remain consistently negative (with one exception) and economically significant both for general training and for employer-arranged training. As expected, the estimates are positive in eight out of ten cases for training on the employee's initiative. The statistical insignificance may be the result of reduced sample size and correspondingly large standard errors.

In sum, there is tentative evidence that parental leave extension has reduced job-related training even for young women without children. Again, it seems that this result is mainly driven by a reduction in employer-arranged training, which has only been partly compensated by training on young female employees' own initiative.

\section{Conclusion}

Even though policies that protect the employment relationships of parents who look after their children for several months or years are contentious on both sides of the Atlantic, maternity or parental leave that guarantees a postleave right to return to work is de facto an important component of family policies in many countries. Whereas some countries like the USA opt for very short maternity leave periods (i.e., 12 weeks), Germany lies at the other extreme, having extended parental leave with a right to return to work with the same employer from between 10 and 18 to 36 months, which ranks in the highest parental/maternity leave durations in industrialized countries. In this paper, we use difference-in-differences and difference-in-trend-shifts estimates to investigate the effect of this extension on the human capital investment of young female workers.

We find significant evidence that parental leave extension reduced employer-arranged training for young women. There is also tentative evidence that young women partly compensated for this reduction in employer-arranged training by undertaking more training on their own initiative.

Taken together with extant findings on extended parental/maternity leave in European countries, our results point to negative economic consequences of protective measures like parental leave (mostly taken by mothers) of up to 3 years (as in Germany) for all young working women, even those without children. These negative effects must be weighted against the potential job security benefits for those who become mothers and the potential benefits for their children. Some regression-controlled estimates suggest that parental leave and mothers' non-participation in the labor market may have positive effects on children's health and test score outcomes Ruhm (2000, 2004). However, as 
the regression discontinuity estimates of Würtz (2007) and Dustmann and Schönberg (2008) show, extended parental leave in Denmark and Germany had no positive effects on children's test scores (Denmark) and attendance of higher track schools or wages (Germany), respectively.

Acknowledgements This research was supported by German Research Foundation within the project "Labour Market Effects of Social Policy" which is part of the research initiative "Flexibility in Heterogeneous Labour Markets." We are grateful to Christian Dustmann, Lena Edlund, Bernd Fitzenberger, Uta Schönberg, Alfonso Sousa-Poza, Marie Waller, two anonymous referees, and seminar participants at the Universities of Darmstadt, Hannover, Hohenheim, Paris II (ERMES), at the research initiative's IAB and ZEW meetings in Nuremberg and Mannheim, respectively, and participants at the Ausschuss für Bildungsökonomie (Bern), EEA (Milan), EALE (Amsterdam), RES (Guildford), SOLE (Boston), and Verein für Socialpolitik (Graz) meetings for helpful comments. All remaining errors are our own.

\section{Appendix 1: Data description}

The three datasets used are the Report System [on] Further Education (Berichtssystem Weiterbildung, BSW), the German Socioeconomic Panel (GSOEP), and the Qualification and Careers Survey (Qualifikation und Berufsverlauf, IAB-BIBB).

The BSW is relatively unknown compared to the other datasets. The BSW survey was conducted seven times (1979, 1982, 1985, 1988, 1991, 1994, 1997, 2000, and 2003) by the Federal Ministry for Education and Research (Bundesministerium für Bildung und Forschung); data are provided by the Central Archive for Empirical Social Research, University of Cologne. Each survey year, about 7,000 persons between 19 and 64 years are interviewed orally (this includes employed and non-employed people). The BSW dataset is at present the only regular representative survey containing all kinds of training incidences in Germany. ${ }^{20}$ In contrast to the other datasets, questions on training are the focus of this survey. We take the year 1988 as observations before and 1994, 1997, and 2003 as observations after the reform. Questions on job-related training refer to the last 12 months.

The GSOEP is an individual-level dataset with panel structure. It is the largest representative longitudinal study of private households in Germany. The same private households, persons, and families have been surveyed annually since 1984. In this dataset, we have information on whether a person took part in job-related training in the last 3 years. Observations before the reform refer to 1989 and observations after the reform to the years 2000 and 2004. The GSOEP has been conducted since 1984, but questions on job-related training

${ }^{20}$ For more information, please see: http://www.bmbf.de/pub/berichtssystem_weiterbildung_9.pdf. 
started in 1989 and were only repeated in 1993, 2000, and 2004. We do not use 1993 because in asking for training during the last 3 years, this wave barely covers the 1992 reform.

The IAB-BIBB data are a representative survey of employed persons, which was conducted in 1985, 1991, and 1998. It focuses on job descriptions and detailed information on qualification profiles and occupational development. Each survey wave consists of more than 34,000 observations; questions on jobrelated training refer to the last 5 years.

Although there are some questions on job-related training in the German Micro Census (Mikrozensus, MZ), this dataset is not suitable for this analysis, because training participation is underrepresented there. ${ }^{21}$ As pointed out by Wohn (2007), there are several reasons why training participation in the MZ is underrepresented compared to the BSW training participation. Since the other two datasets (GSOEP and IAB-BIBB) have comparable training incidences to the BSW, we focus on these three datasets in the regression analyses and use the Micro Census data only for descriptive analyses (see Fig. 2a-c).

The choice of datasets is driven by information on job-related training at the individual level both before and after the parental leave extension of 1992. Because the treatment group comprises all women of childbearing age, actual information on parental leaves of the mother was not required for a dataset to be used here. Nevertheless, problems do arise in the dataset comparison. First, all three datasets measure the outcome variable, job-related training, for a different period of time: the last 5 years in the IAB-BIBB data, the last 3 years in the GSOEP, and the last 12 months in the BSW. The second difficulty stems from the needs of our difference-in-differences analysis. Not only does it require training incidence observations before and after the parental leave extension, but these can only be done properly by focusing on the most drastic reform, that which lengthens parental leave from 18 to 36 months. However, the post-1992 reform surveys differ enormously in timing: 1994 for the BSW, 1998 for the IAB-BIBB, and 2000 for the GSOEP.Variation also exists in the timing of the pre-1992 reform surveys, which refer to the following years: BSW, 1988; GSOEP, 1989; and IAB-BIBB, 1991. Obviously, these differences must be taken into account. For example, by asking for training in the 5 years previous to 1991, the pre-reform survey refers to a period during which three smaller extensions of parental leave benefits occurred (see the gray-shaded boxes in Fig. 2a-c). The surveys also differ somewhat in their sample sizes, with the largest, the IAB-BIBB, containing more than 16,000 observations per wave. GSOEP and BSW are smaller, the former with over 2,700 observations in 1989 but more than 5,000 in 2000 because of refreshment samples, and the latter with more than 3,000 and 2,000 observations before and after the reform, respectively.

\footnotetext{
${ }^{21}$ In our analysis, training participation in the Micro Census was only less than half as high as in the other three datasets.
} 


\section{Appendix 2}

Table 9 Summary statistics

\begin{tabular}{|c|c|c|c|c|c|c|c|c|c|}
\hline & \multicolumn{4}{|l|}{ BSW } & \multicolumn{3}{|c|}{ GSOEP } & \multicolumn{2}{|c|}{ IAB-BIBB } \\
\hline & 1988 & 1994 & 1997 & 2003 & 1989 & 2000 & 2004 & 1991 & 1998 \\
\hline Training (All) & 0.25 & 0.33 & 0.44 & 0.37 & 0.30 & 0.36 & 0.35 & 0.35 & 0.42 \\
\hline High school & 0.20 & 0.25 & 0.27 & 0.25 & 0.20 & 0.30 & 0.32 & 0.18 & 0.26 \\
\hline University & 0.15 & 0.17 & 0.19 & 0.17 & 0.12 & 0.20 & 0.25 & 0.16 & 0.14 \\
\hline Age & 37.2 & 37.8 & 38.2 & 39.6 & 37.1 & 39.0 & 40.9 & 36.9 & 38.2 \\
\hline Age between 20 and 35 & 0.51 & 0.51 & 0.49 & 0.41 & 0.53 & 0.45 & 0.35 & 0.54 & 0.48 \\
\hline White-collar worker & 0.53 & 0.53 & 0.60 & 0.59 & 0.53 & 0.61 & 0.62 & 0.51 & 0.56 \\
\hline Blue-collar worker & 0.34 & 0.34 & 0.29 & 0.31 & 0.36 & 0.30 & 0.27 & 0.40 & 0.34 \\
\hline Civil servant & 0.12 & 0.13 & 0.11 & 0.10 & 0.11 & 0.10 & 0.11 & 0.09 & 0.10 \\
\hline Female & 0.40 & 0.39 & 0.42 & 0.46 & 0.42 & 0.44 & 0.47 & 0.41 & 0.43 \\
\hline Married & 0.68 & 0.66 & 0.67 & 0.68 & 0.58 & 0.55 & 0.64 & 0.75 & 0.74 \\
\hline Children & 0.41 & 0.48 & 0.45 & 0.46 & 0.31 & 0.32 & 0.39 & 0.34 & 0.42 \\
\hline Working full-time & 0.83 & 0.81 & 0.80 & 0.72 & 0.86 & 0.81 & 0.77 & 0.88 & 0.84 \\
\hline$n$ & 3,112 & 2,147 & 1,984 & 1,846 & 2,764 & 5,639 & 4,823 & 16,682 & 17,564 \\
\hline
\end{tabular}

Source: Report System Further Education (BSW); German Socio-Economic Panel (GSOEP); Qualification and Careers (IAB-BIBB); own calculations

\section{Appendix 3}

Table 10 Before-after estimates (including control variables stepwise)

\begin{tabular}{|c|c|c|c|c|}
\hline & $(1)$ & $(2)$ & (3) & (4) \\
\hline \multicolumn{5}{|c|}{ BSW-Training in general } \\
\hline Young women & 0.045 & $0.063^{b}$ & $0.056^{\mathrm{a}}$ & $0.057^{\mathrm{a}}$ \\
\hline$n=1,188$ & $(0.03)$ & $(0.031)$ & $(0.031)$ & $(0.031)$ \\
\hline Older women & $0.097^{\mathrm{c}}$ & $0.090^{\mathrm{c}}$ & $0.086^{\mathrm{c}}$ & $0.088^{c}$ \\
\hline$n=1,016$ & $(0.029)$ & $(0.029)$ & $(0.029)$ & $(0.029)$ \\
\hline Young men & $0.048^{\mathrm{a}}$ & $0.049^{\mathrm{a}}$ & $0.062^{\mathrm{b}}$ & $0.061^{b}$ \\
\hline$n=1,405$ & $(0.028)$ & $(0.03)$ & $(0.029)$ & $(0.029)$ \\
\hline Older men & $0.103^{c}$ & $0.089^{c}$ & $0.097^{\mathrm{c}}$ & $0.101^{\mathrm{c}}$ \\
\hline$n=1,456$ & $(0.026)$ & $(0.027)$ & $(0.026)$ & $(0.027)$ \\
\hline \multicolumn{5}{|c|}{ BSW-Training arranged by employer } \\
\hline Young women & 0.014 & 0.027 & 0.025 & 0.025 \\
\hline$n=1,188$ & $(0.023)$ & $(0.024)$ & $(0.024)$ & $(0.024)$ \\
\hline Older women & $0.072^{\mathrm{c}}$ & $0.073^{\mathrm{c}}$ & $0.071^{\mathrm{c}}$ & $0.073^{\mathrm{c}}$ \\
\hline$n=1,016$ & $(0.022)$ & $(0.023)$ & $(0.022)$ & $(0.022)$ \\
\hline Young men & $0.060^{\mathrm{b}}$ & $0.066^{\mathrm{b}}$ & $0.074^{\mathrm{c}}$ & $0.070^{\mathrm{c}}$ \\
\hline$n=1,405$ & $(0.023)$ & $(0.025)$ & $(0.025)$ & $(0.025)$ \\
\hline Older men & $0.061^{\mathrm{c}}$ & $0.053^{\mathrm{b}}$ & $0.059^{\mathrm{b}}$ & $0.062^{\mathrm{c}}$ \\
\hline$n=1,456$ & $(0.023)$ & $(0.024)$ & $(0.024)$ & $(0.024)$ \\
\hline \multicolumn{5}{|c|}{ BSW-Training on one's own initiative } \\
\hline Young women & $0.045^{\mathrm{a}}$ & $0.051^{\mathrm{a}}$ & $0.046^{\mathrm{a}}$ & $0.045^{\mathrm{a}}$ \\
\hline$n=1,188$ & $(0.025)$ & $(0.027)$ & $(0.026)$ & $(0.027)$ \\
\hline Older women & $0.057^{b}$ & $0.049^{\mathrm{b}}$ & $0.048^{c}$ & $0.047^{c}$ \\
\hline$n=1,016$ & $(0.023)$ & $(0.023)$ & $(0.023)$ & $(0.023)$ \\
\hline Young men & 0.002 & 0.001 & 0.007 & 0.01 \\
\hline$n=1,405$ & $(0.022)$ & $(0.023)$ & $(0.023)$ & $(0.024)$ \\
\hline Older men & $0.069^{c}$ & $0.060^{\mathrm{c}}$ & $0.065^{\mathrm{c}}$ & $0.066^{\mathrm{c}}$ \\
\hline$n=1,456$ & $(0.019)$ & $(0.02)$ & (0.019) & $(0.02)$ \\
\hline
\end{tabular}


Table 10 (continued)

\begin{tabular}{ccccc}
\hline & $(1)$ & $(2)$ & $(3)$ & $(4)$ \\
\hline GSOEP-Training in general & & & & \\
Young women & 0.04 & 0.016 & 0.008 & 0.002 \\
$n=1,716$ & $(0.03)$ & $(0.03)$ & $(0.029)$ & $(0.03)$ \\
Older women & $0.179^{\mathrm{c}}$ & $0.138^{\mathrm{c}}$ & $0.127^{\mathrm{c}}$ & $0.128^{\mathrm{c}}$ \\
$n=1,849$ & $(0.025)$ & $(0.025)$ & $(0.024)$ & $(0.024)$ \\
Young men & 0.003 & -0.029 & -0.019 & -0.004 \\
$n=2,175$ & $(0.029)$ & $(0.029)$ & $(0.028)$ & $(0.028)$ \\
Older men & $0.053^{\mathrm{b}}$ & 0.02 & $0.038^{\mathrm{a}}$ & $0.039^{\mathrm{a}}$ \\
$n=2,539$ & $(0.025)$ & $(0.023)$ & $(0.023)$ & $(0.023)$ \\
IAB-BIBB-Training in general & & & \\
Young women & $0.036^{\mathrm{b}}$ & 0.015 & 0.012 & 0.012 \\
$n=7,513$ & $(0.012)$ & $(0.012)$ & $(0.012)$ & $(0.012)$ \\
Older women & $0.136^{\mathrm{c}}$ & $0.116^{\mathrm{c}}$ & $0.109^{\mathrm{c}}$ & $0.104^{\mathrm{c}}$ \\
$n=6,823$ & $(0.012)$ & $(0.012)$ & $(0.011)$ & $(0.012)$ \\
Young men & $0.022^{\mathrm{a}}$ & -0.003 & -0.002 & 0.006 \\
$n=9,560$ & $(0.011)$ & $(0.011)$ & $(0.01)$ & $(0.01)$ \\
Older men & $0.118^{\mathrm{c}}$ & $0.098^{\mathrm{c}}$ & $0.088^{\mathrm{c}}$ & $0.085^{\mathrm{c}}$ \\
$n=10,072$ & $(0.011)$ & $(0.011)$ & $(0.01)$ & $(0.01)$ \\
\hline
\end{tabular}

The four columns represent four different specifications where control variables are added stepwise. The first specification shows the raw effect, i.e. no control variables are included. We then successively increase the set of control variables in specifications 2 through 4 , first by including dummy variables for education (i.e., high school diploma/A-level/Abitur and a tertiary polytechnic or university degree) and controlling for age and age squared. In specification 3 , we also add job characteristics using dummy variables for full-time, white-collar, and civil servant employment. Finally, in specification 4 we incorporate dummy variables for civil status (i.e., for being married and having children). Source: Report System Further Education (BSW); German Socio-Economic Panel (GSOEP); Qualification and Careers (IAB-BIBB); own calculations

${ }^{\text {a }}$ Significance at the $10 \%$

${ }^{\mathrm{b}}$ Significance at the $5 \%$

${ }^{\mathrm{c}}$ Significance at the $1 \%$

\section{References}

Auer P, Cazes S (2000) The resilience of the long-term employment relationship: evidence from the industrialized countries. Int Labour Rev 139(4):379-408

Barron JM, Black DA, Loewenstein MA (1993) Gender differences in training, capital, and wages. J Hum Resour 28(2):343-364

Baum CL (2003) The effect of state maternity leave legislation and the 1993 family and medical leave act on employment and wages. Labour Econ 10(5):573-596

Bertrand M, Duflo E, Mullainathan S (2004) How much should we trust differences-indifferences? Q J Econ 119(1):249-275

Dienel Ch (2002) Familienpolitik [Family policy, in German]. Juventa, Weinheim

Dustmann Ch, Schönberg U (2008) The effect of expansions in leave coverage on children's longterm outcomes. IZA, Bonn, Discussion Paper No. 3605

Green F (1991) Sex discrimination in job-related training. Br J Ind Relat 29(2):295-304

Gruber J (1994) The incidence of mandated maternity benefits. Am Econ Rev 84(3):622-641

Gustafsson SS, Wetzels CMMP, Vlasblom JD et al (1996) Women's labor force transitions in connection with children: a panel data comparison between Germany, Sweden and Great Britain. J Popul Econ 9(3):223-246

Gutiérrez-Domènech M (2005) Employment after motherhood: a European comparison. Labour Econ 12(1):99-123 
Hashimoto M (1981) Firm-specific human capital as a shared investment. Am Econ Rev 71(3):475482

Hashimoto M, Percy R, Schoellner T et al (2004) The long and short of it: maternity leave coverage and women's labor market outcomes. IZA, Bonn, Discussion Paper No. 1207

Klerman JA, Leibowitz A (1990) Child care and women's return to work after childbirth. Am Econ Rev 80(2):284-288

Kreyenfeld M (2001) Employment and fertility-East Germany in the 1990s. Rostock University, doctoral thesis

Lai Y-Ch, Masters S (2005) The effects of mandatory maternity and pregnancy benefits on women's wages and employment in Taiwan, 1984-1996. Ind Labor Relat Rev 58(2):274-281

Lalive R, Zweimüller J (2005) Does parental leave affect fertility and return-to-work? Evidence from a "True Natural Experiment". IZA, Bonn, Discussion Paper No. 1613

Lazear E (1990) Job security provisions and employment. Q J Econ 105(3):699-726

Ondrich J, Spiess CK, Yang Q (1996) Barefoot and in a German kitchen: federal parental leave and benefit policy and the return to work after childbirth in Germany. J Popul Econ 9(3):247266

Ondrich J, Spiess CK, Yang Q et al (1999) Full time or part time? German parental leave policy and the return to work after childbirth in Germany. Res Labor Econ 18:41-74

Ondrich J, Spiess CK, Yang Q et al (2003) The liberalization of maternity leave policy and the return to work after childbirth in Germany. Review of Economics of the Household 1(1-2):77110

Puhani PA, Sonderhof K (2008) The effects of maternity leave extension on training for young women. IZA, Bonn, Discussion Paper No. 3820

Royalty AB (1996) The effects of job turnover on the training of men and women. Ind Labor Relat Rev 49(3):506-521

Ruhm Ch J (1998) The economic consequences of parental leave mandates: lessons from Europe. Q J Econ 113(1):285-317

Ruhm Ch J (2000) Parental leave and child health. J Health Econ 19(6):931-960

Ruhm Ch J (2004) Parental employment and child cognitive development. J Hum Resour 39(1):155-192

Schönberg U, Ludsteck J (2007) Maternity leave legislation, female labor supply, and the family wage gap. IZA, Bonn, Discussion Paper No. 2699

Spitz-Öner A (2006) Technical change, job tasks and rising educational demands: looking outside the wage structure. J Labor Econ 24(2):235-270

Waldfogel J (1998) The family gap for young women in the United States and in Britain: can maternity leave make a difference? J Labor Econ 16(3):505-545

Waldfogel J (1999) The impact of the family and medical leave act. J Policy Anal Manage 18(2):281-302

Waldfogel J, Berger LM (2004) Maternity leave and the employment of new mothers in the United States. J Popul Econ 17(2):331-349

Waldfogel J, Higuchi Y, Abe M (1999) Family leave policies and women's retention after childbirth: evidence from the United States, Britain, and Japan. J Popul Econ 12(4):523-545

Weber AM (2004) Wann kehren junge Mütter auf den Arbeitsmarkt zurück? Eine Verweildaueranalyse für Deutschland [When Do Young Mothers Return to the Labor Market, A Duration Analysis for Germany, in German]. ZEW, Mannheim, Discussion Paper No. 04-08

Wohn K (2007) Effizienz von Weiterbildungsmessung [Efficiency of Measuring Training Participation, in German]. Rat für Sozial- und Wirtschaftsdaten [German Council for Social and Economic Data] Working Paper No. 19

Würtz A (2007) The long-term effect on children of increasing the length of parents' birth-related leave, Aarhus School of Business, Department of Economics Working Paper 07-11

Zveglich JE Jr, van der Meulen Rodgers Y (2003) The impact of protective measures for female workers. J Labor Econ 21(3):533-555 